\title{
ARTYKULY
}

\section{OSADNICY, TWIERDZE, TEMY. \\ BIZANTYŃSKIE DZIAŁANIA W CELU WZMOCNIENIA GRANICY Z WCZESNOŚREDNIOWIECZNĄ BUŁGARIĄ, VII-X W.}

\begin{abstract}
KIRIŁ MARINOW
ABstract. Settlers, strongholds, themes. Byzantine activities to strengthen the border with Early Medieval Bulgaria, $7^{\text {th }}-10^{\text {th }} \mathrm{c}$.

The article raises issues related to the Byzantine reconquista of the Thracian and Macedonian lands after the period of barbarian invasions on the Balkan Peninsula in the $5^{\text {th }}-7^{\text {th }} \mathrm{c}$. When implementing the plan to recover these areas, the authorities in Constantinople had to take into account the real threat from the Bulgarian Khanate, established north of the Haimos Mountains. Bulgarians threatened not only the success of the Byzantine venture, but they went much further south, reaching in their raids the surroundings of the imperial capital (in the southeast) or the geographical and historical lands of Macedonia (in the southwest). To remedy this, and to make their presence more real in these areas, the emperors moved there the population from Asia Minor to fulfill the existing settlement voids, embedding them in already existing or newly built fortresses and cities (as garrison units), or on arable lands (rural settlement). Another step was the creation of specific administrative units in the indicated areas, through which it was easier to administer them and effectively organize resistance against invaders from the north. Local settlers also constituted the basic military force obliged to protect these border territories. On the other hand, Thracian strongholds played the role of Byzantine outposts and bases for imperial expeditions organized against Bulgaria itself.
\end{abstract}

STreszczenie. Osadnicy, twierdze, temy. Bizantyńskie działania w celu wzmocnienia granicy z wczesnośredniowieczna Butgaria, VII-Xw.

Artykuł podnosi zagadnienia związane z bizantyńską rekonkwistą ziem trackich i macedońskich po okresie najazdów barbarzyńskich na Półwysep Bałkański w V-VII w. n.e. Realizując plan odzyskiwania tych terenów władze w Konstantynopolu musiały brać pod uwagę realne zagrożenie ze strony chanatu bułgarskiego, funkcjonującego na północ od gór Hemos. Bułgarzy bowiem zagrażali nie tylko powodzeniu bizantyńskiego przedsięwzięcia, lecz wyprawiali się znacznie dalej na południe, sięgając w swych rajdach okolic cesarskiej stolicy (na południowym wschodzie) czy ziem geograficzno-historycznej Macedonii (na południowym zachodzie). By temu zaradzić, a i urealnić swoją obecność na wspomnianych obszarach, cesarze sprowadzali ludność małoazjatycką, którą uzupełniano istniejące tam pustki osadnicze, osadzając ją w już istniejących lub nowo wzniesionych twierdzach i miastach (jako oddziały garnizonowe), bądź na terenach uprawnych (osadnictwo wiejskie). Innym krokiem było utworzenie na wskazanych terenach konkretnych jednostek administracyjnych, za pośrednictwem których łatwiej było nimi zarządzać i skutecznie organizować opór przeciwko najeźdźcom z północy. Miejscowi osadnicy stanowili również podstawową siłę militarną zobowiązaną do ochrony tych pogranicznych terytoriów. $\mathrm{Z}$ drugiej strony twierdze trackie pełniły rolę bizantyńskich forpoczt i baz wypadowych dla wypraw cesarskich organizowanych przeciwko samej Bułgarii.

Author: Kirił Marinow, Uniwersytet Łódzki, Wydział Filozoficzno-Historyczny, Instytut Historii, Katedra Historii Bizancjum, ul. Aleksandra Kamińskiego 27a, 90-219 Łódź, kiril.marinow@uni.lodz.pl, ORCID iD: https://orcid.org/0000-0003-0224-3965

Keywords: Byzantium, medieval Bulgaria, Byzantine-Bulgarian relationships, the Balkans, Byzantine defencesystem, inter-state borders, medieval towns and fortresses

Słowa kluczowe: Bizancjum, średniowieczna Bułgaria, relacje bizantyńsko-bułgarskie, Bałkany, bizantyński system obronny, granice międzypaństwowe, średniowieczne miasta i twierdze

Balcanica Posnaniensia. Acta et studia, XXVI, Poznań 2019, Wydawnictwo Instytutu Historii UAM, pp. 5-31, ISBN 978-83-66355-32-3, ISSN 0239-4278. Polish text with summaries in English and Polish.

doi.org/10.14746/bp.2019.26.1 
Powstanie chanatu Bułgarów na terytoriach bizantyńskich nad Dolnym Dunajem w ostatniej ćwierci VII stulecia skomplikowało sytuację geopolityczną imperium ${ }^{1}$. Oto bowiem stosunkowo niedaleko głównej siedziby władz cesarskich - stołecznego Konstantynopola i jego bezpośredniego hinterlandu - pojawiła się nowa siła polityczna, która stwarzała zagrożenie nie tylko dla terytoriów realnie wówczas podlegających cesarzowi znad Bosforu, lecz również tych, które miał dopiero zamiar odzyskać, głownie w Tracji i Macedonii. Bułgarzy przeistoczyć się mogli, co rzeczywiście się stało, w rywali Bizancjum, którzy uniemożliwią mu lub co najmniej utrudnią rekonkwistę dawnych ziem, straconych, lub wyludnionych, w wyniku najazdów barbarzyńskich V-VII w. ${ }^{2}$

Cesarstwo nie pozostało więc obojętne na utratę kontroli nad Równiną Naddunajską i przesunięcie północnej granicy imperium z koryta dolnego Dunaju na południowe stoki masywu Hemosu (składającego się ze współczesnych pasm Przedbałkanu, Starej Płaniny i Srednej Gory), w okresie osmańskim zwanego Bałkanem³ ${ }^{3}$. W związku ze stratą tych gór (w tym wiodących przez nie przełęczy, umożliwiających przedostanie się na południe od tego masywu), dotychczas broniących dostępu do Tracji, Bizancjum musiało przeorganizować swój system obronny na tym ostatnim terenie. Obszary trackie stanowiły bowiem naturalne zaplecze Konstantynopola i odgrywały istotną rolę w obronie bizantyńskiej stolicy. Tym samym wydatnie wzrosło znaczenie następnej naturalnej przeszkody na drodze wiodącej z północy Bałkanów do Konstantynopola, a mianowicie pasa gór Strandża (tu rozumianego łącznie z pomniejszymi pasmami - Sakar i Hasekijata). Szczególnie istotny był fakt, że obejście tego masywu sięgającego na wschodzie wybrzeża morskiego, było utrudnione

\footnotetext{
${ }^{1} \mathrm{Na}$ temat powstania chanatu bułgarskiego nad Dolnym Dunajem vide m.in. następujące prace przeglądowe - W. Swoboda, Powstanie państwa butgarskiego na tle stowiańskich procesów państwowotwórczych na Bałkanach, w: 1300-lecie państwa butgarskiego 681-1981. Materiały z sesji naukowej, red. T. Zdancewicz, Poznań 1983, s. 67-76; T. Wasilewski, Kontrowersje wokót powstania i najstarszych dziejów państwa bułgarskiego, w: Trzynaście wieków Bułgarii. Materiały polsko-bułgarskiej sesji naukowej, Warszawa 28-30 X 1981, red. J. Siatkowski, Wrocław 1983, s. 181-189; Г.Г. Литаврин, K проблеме становления болгарского государства, w: idem, Византия и славяне (сборник статей), Санкт-Петербург 1999, s. 192-217.

${ }^{2} \mathrm{Na}$ temat tych najzadów vide m.in. M. Whitby, The Emperor Maurice and his historian: Theophylact Simocatta on Persian and Balkan warfare, Oxford 1988, s. 140-183; W. Pohl, Die Awaren: ein Steppenvolk im Mitteleuropa, 567-822 n. Chr., Munich 1988, s. 76-162; E.A. Thompson, The Huns, Oxford 1996, s. 33, 81-104; B. Croke, Count Marcellinus and his Chronicle, Oxford 2001, s. 67-69; F. Haarer, Anastasius I: Politics and Empire in the Late Roman world, Cambridge 2006, s. 104-106; J.H.W.G. Liebeschuetz, The Lower Danube region under pressure: from Valens to Heraclius, w: The transition to Late Antiquity: on the Danube and beyond, red. A. Poulter, Oxford 2007, s. 101-134; C. Kelly, Attila the Hun: Barbarian terror and the fall of the Roman Empire, London 2008, rozdz. 10-12; A. Sarantis, Justinian's Balkan Wars: campaigning, diplomacy and development in Illyricum, Thrace and the Northern World, A.D. 527-565, Cambridge 2016, s. 21-33, 83-84, 101-109, 251-252, 278-300, 336-349.

${ }^{3} \mathrm{Na}$ temat tych gór i ich znaczenia historycznego w omawianym okresie vide $\mathrm{K}$. Marinow, The Haemus Mountains and the Geopolitics of the First Bulgarian Empire: An Overview, “Зборник радова Византолошког института", 2014, nr 51, s. 17-32.
} 
przez dochodzący do niego od zachodu masyw Rodopów ${ }^{4}$. Tak więc w drodze do bizantyńskiej stolicy Bułgarzy musieli pokonać Strandżę. Wyrwę w tym ciągu wzniesień czyniła jedynie dolina rzeki Hebros (dz. Marica), która oddzielała Strandżę od Rodopów. To właśnie wzdłuż jej nurtu, pomiędzy oboma masywami, ciągnęła się słynna via militaris, łącząca naddunajskie Singidunum (Belgrad) z nadbosforskim Konstantynopolem ${ }^{5}$. Dostępu do stolicy bizantyńskiej na odcinku tej drogi biegnącym pomiędzy wspomnianymi dwoma masywami górskimi strzegła twierdza adrianopolska.

Po zagarnięciu przez Bułgarów klisur (tzn. przełęczy górskich) Hemosu dla obrony Bizancjum przed inwazją z północy wzrosła również rola pozostałych ośrodków miejskich na wspomnianej trasie wojskowej łączącej dolinę wielkiej rzeki z obszarami nad Propontydą. Miasta te, mianowicie Naissos, Sardyka, Filipopol i wspomniany Adrianopol ${ }^{6}$ spełniały rolę głównych zapór na drodze Bułgarów ku południu (Tracji Egejskiej) i południowemu zachodowi (Macedonii). Zwłaszcza Sardyka i Filipopol zyskały na znaczeniu, gdyż znajdowały się po obu stronach newralgicznego odcinka omawianej trasy, a mianowicie przełęczy Succi, zwanej także Klisurą Cesarską, a w epoce osmańskiej Bramą Trajana, która umożliwiała kontrolę nad dostępem i przepływem ludzi i dóbr między Centralną Europą, konkretnie zaś Panonią, a bałkańską Tracją, a w szerszym ujęciu Azją Mniejszą. Wskazane przejście górskie znajdowało się (i nadal się znajduje) na terenie masywu Ichtimanskiej Srednej Gory, a zatem w najbardziej południowej partii starożytnego i średniowiecznego Hemosu? Sardyka flankowała dostęp do niego od północnego zachodu, Filipopol natomiast od południowego wschodu. Oba stanowiły ostatnie znaczące przystanki i forpoczty bizantyńskie przed wkroczeniem do wskazanej przełęczy. Z drugiej zaś strony strzegły, przede wszystkim Filipopol, dostępu do żyznych i newralgicznych terytoriów trackich. Przejęcie tych ośrodków przez Bułgarów, a zwłaszcza Sardyki, będącej najważniejszym umocnieniem bizantyńskim umożliwiającym kontrolę nad strategicznym obszarem tzw. Kotliny Sofijskiej, groziło blokadą omawianej klisury i odcięciem znajdującego się dalej na północy Naissos. Potencjalnie istniało także niebezpieczeństwo kontrolowania samej przełęczy, czy też organizowania w niej zasadzek na podróżnych bezpośrednio z kierunku północnego, gdyż Sredna Gora łączy się z masywem staropłanińskim za pośrednictwem czterech siodeł górskich oraz leżących

${ }^{4}$ В. Кецкаров, Укрепителната организация на България и Византия от VII до IX век, „Родина”, 1940 , nr 2.3, s. 39, 42-44.

${ }^{5} \mathrm{O}$ tej trasie vide K.J. Jireček, Die Heerstrasse von Belgrad nach Constantinopel und die Balkanpässe. Eine Historisch-Geographische Studie, Prag 1877; П. Мутафчиев, Старият друм през „Траянови враma”, „Списание на Българската академия на науките. Клон Историко-филологичен и Философско-обществен", 1937, nr 55 (27), s. 19-148.

${ }^{6}$ Chodzi kolejno o dzisiejszy Nisz (Serbia), Sofię i Płowdiw (Bułgaria) oraz Edirne (Turcja).

7 Na temat tej przełęczy vide П. Мутафчиев, op. cit.; Д. Митова-Джонова, Confinium Succi u Mutatio Sonеiит през античността и ранновизантийската епоха, „Анали”, 1994, nr 1.2/3, s. 77-99. 
pomiędzy nimi Kotlin Subbałkanskich ${ }^{8}$. A zatem istniało niebezpieczeństwo, że pod osłoną tego ostatniego masywu Bułgarzy będą penetrować okolice tego newralgicznego odcinka via militaris.

Bizancjum przywiązywało również większe znaczenie do pomniejszych twierdz i miast rozsianych na obszarze Tracji. Mogły one bowiem utrudniać posuwanie się przeciwnika w stronę cesarskiej stolicy, szczególnie na linii Północ-Południe. Nie zrezygnowało nigdy $\mathrm{z}$ ustanowienia swej władzy przynajmniej na południowych stokach Hemosu, tak, by już u jego podnóży, w początkowej jeszcze fazie bułgarskich poczynań wojennych, stawić im opór i zahamować dalsze postępy wroga. Panowanie nad podnóżami gór i południowymi stokami Bałkanu umożliwiało Bizantyńczykom dogodną koncentrację wojsk tuż nad nieprzyjacielską granicą i przeprowadzanie manewrów mających na celu ominięcie fortyfikacji staropłanińskich oraz wkroczenie do Bułgarii najmniej spodziewaną dla wrogów przełęcząa . Funkcjonujące u podnóży gór twierdze nie tylko wyznaczały zasięg realnej władzy cesarskiej na tym obszarze, pozwalały kontrolować napływ ludności z kierunku północnego, lecz gwarantowały także dogodne i stosunkowo bezpieczne miejsce odpoczynku dla armii cesarskiej wyprawiającej się na północnych sąsiadów.

Przekazy patriarchy Nikefora i Teofanesa Wyznawcy wyraźnie podają, że w pierwszym okresie po opanowaniu przez Bułgarów Scytii Mniejszej i Mezji Dolnej pasmo staropłanińskie stanowiło granicę polityczną z południowym sąsiadem Bułgarii ${ }^{10}$. Przybycie Bułgarów nad Dolny Dunaj skutkowało powstaniem w okresie pomiędzy latami 680-687 pierwszej jednostki temowej na obszarze europejskich włości cesarstwa, mianowicie temu Tracji ${ }^{11}$. W swym dziele o temach, cesarz Konstantyn VII

${ }^{8}$ Z. Czeppe, J. Flis, R. Mochnacki, Geografia fizyczna świata, Warszawa 1969, s. 239, 240; Г.Д. Данов, Средна Гора. Пътеводител, София 1971, s. 9, 10; H. Maruszczak, Butgaria, Warszawa 1971, s. 124, 316-317; Св. Кираджиев, Енииклопедичен географски речник на България, ${ }^{2}$ София 2013, s. 163, 227, 246-247, 264-265, 279, 348, 515, 529.

9 П. Мутафчиев, Балканът в намата история, w: idem, Книга за българите, red. В. Гюзелев, София 1987, s. 70-71.

${ }^{10}$ Nicephori Patriarchae Constantinopolitani breviarium historicum, 36, wyd. C. Mango, Washingtoniae D.C. 1990, 90, 19-23; Theophanis chronographia, AM 6171, wyd. Carl de Boor, t. I, Lipsiae 1883, s. $359,5-12$.

${ }^{11}$ T. Wasilewski, Bizancjum i Stowianie w IX wieku. Studia z dziejów stosunków politycznych i kulturalnych, Warszawa 1972, s. 26; Les listes de préséance byzantines des IXe et Xe siècles, wyd. N. Oikonomidès, Paris 1972, s. 349, 355; Z. Kurnatowska, Stowiańszczyzna Poludniowa, Wrocław-Warszawa-KrakówGdańsk 1977, s. 45; W. Swoboda, Tema, w: Stownik Starożytności Stowiańskich. Encyklopedyczny zarys kultury Stowian od czasów najdawniejszych do schyłku wieku XII, t. VI, T-W, red. G. Labuda, Z. Stieber, Wrocław 1977, s. 46 (zaraz po 680 r.); idem, Tracja, w: Stownik..., s. 122 (przed 687 r.); П. Коледаров, Политическа география на средновековната българска държава, t. I, Oт 681 до 1018 г., София 1979, s. 8; idem, Образуване на тема „Македония” в Тракия, „Известия на Института за история”, 1979, nr 21, s. 220 (datuje powstanie temu na około 680 r.); J.V.A. Fine jr., The Early Medieval Balkans. A Critical Survey from the Sixth Century to the Late Twelfth Century, Ann Arbor 1983, s. 70; В. Поповић, Куврат, Кубер и Аспарух, „Старинар”, 1986, nr 37, s. 122; Д. Ангелов, Византия. Възход и залез на една империя, София 1991, s. 123-124; P. Soustal, Thrakien (Thrakē, Rodopē und Haimimontos), Tabula Imperii Byzantini, t. VI, Wien 1991, s. 49, 76; Ив. Йорданов, Печатите от стратегията в Преслав (971-1088), София 1993, s. 125 (przyjmuje datację na 679-680 r.); W. Treadgold, A History 
Porfirogeneta (913-959) potwierdził, że zorganizowanie tej jednostki administracyjno-wojskowej związane było m.in. z przekroczeniem przez Bułgarów rzeki Dunaj i osiedleniem się ich na ziemiach na północ od Starej Płaniny ${ }^{12}$.

Dokładne granice jednostki nie są znane. Najczęściej przyjmuje się, że miała początkowo obejmować tylko dawną prowincję Europę z ośrodkiem w Arkadiopolu ${ }^{13}$, a więc terytoria wokół bizantyńskiej stolicy ${ }^{14}$. A zatem obszary na zachód od tzw. Długich Murów cesarza Anastazjusza (491-518), sięgające na północy Deweltu ${ }^{15}$, na północnym zachodzie okolic Adrianopola ${ }^{16}$. Niewykluczone jednak, że Bizantyńczycy przynajmniej w pierwotnym założeniu zakładali, że północne granice temu będą sięgać południowych stoków Starej Płaniny, a więc obejmować obszary nie zajęte przez Bułgarów. Zdaje się to sugerować sam tekst uczonego cesarza. Konstantyn przypominał bowiem, że w przeszłości ziemie zajmowane przez państwo bułgarskie wchodziły w skład bizantyńskiej diecezji Tracji. Ta ostatnia zaś obejmowała terytoria wokół Dunaju i gór Hemos ${ }^{17}$. Skoro więc u schyłku VII w. tereny te odpadły od Bizancjum, logiczne mogłoby się wydawać, że w ramach cesarstwa pozostała reszta ziem, których Bułgarzy nie zajęli. Ówczesny więc cesarz, Konstantyn IV Pogonat (668-685), musiał zatem zredukować Trację do rangi temu ${ }^{18}$ i ograniczyć jej terytorium, gdyż jej dawne północne tereny dostały się pod władanie Bułgarów ${ }^{19}$.

of the Byzantine State and Society, Stanford 1997, s. 329-330 (datuje około 681 r.); В. Гюзелев, Езическа България, w: Ив. Божилов, В. Гюзелев, История на средновековна България VII-XIV век, София 1999, s. 93 (datę powstania temu zawęża do 680-września 685 r., czyli za rządów Konstantyna IV);

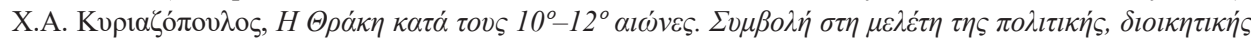

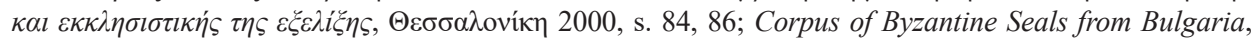
vol. I, Byzantine Seals with Geographical Names, ed. idem, Sofia 2003, s. 92-98 (nr 35-35.8.12-13); Хр. Матанов, Балкански хоризонти. История, общества, личности, t. I, София 2004, s. 30; J. Koder,

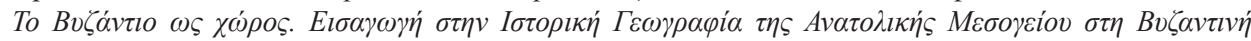

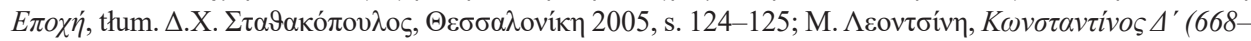

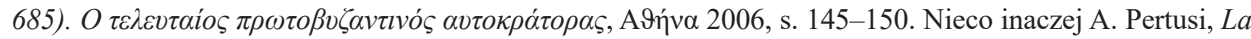
formation des thèmes byzantines, w: Berichte zum XI. Internationalen Bizantinisten-Kongreß, München 1958, s. 38-39 (Trację wyodrębniono w niezależną od Opsikionu jednostkę temową pomiędzy 679-711 r.); J. Irmscher, Die Begründung des Themas Thrake, „Studia Balcanica”, 1975, nr 10, s. 101-103.

12 Constantino Porfirogenito, De thematibus, 44, wyd. A. Pertusi, Città di Vaticano 1952, s. 84, 5-7, s. $85,25-30$ (komentarz na s. 156-160).

${ }^{13}$ Dzis. Lüleburgaz w Turcji.

${ }^{14}$ W. Swoboda, Tracja..., s. 122; П. Коледаров, Политическа география..., s. 8; P. Soustal, op. cit., s. 49.

${ }^{15}$ Dzis. Debelt w Bułgarii.

${ }^{16} \mathrm{~N}$. Oikonomidès, $\dot{A}$ propos de la première occupation byzantine de la Bulgarie (971 - ca 986), w: Eupsycheía. Mélanges H. Ahrweiler, t. II, Paris 1998, s. 583.

${ }^{17}$ J. Koder, op. cit., s. 111; cf. Corpus of Byzantine..., s. 93 (nr 35.1A-B).

18 Oczywiście umownie, gdyż system temowy stanowił zupełnie nowy sposób podziału administracyjnego terytoriów bizantyńskich, nie mający wiele wspólnego z podziałem z czasów reform cesarzy Dioklecjana (284-305) i Konstantyna I (306-337).

${ }^{19}$ Taki sam zasięg tego temu na północy, bez podawania jakiejkolwiek argumentacji, powołując się jedynie na literaturę przedmiotu, przyjmuје Ив. Йорданов, op. cit., s. 125; Corpus of Byzantine ..., s. 92 (nr 35). 
Na uwagę zasługuje fakt, że po opisie wszystkich prowincji wchodzących niegdyś w skład Tracji Konstantyn VII stwierdził, iż dotąd sięga tem Tracji, a więc do obszaru zajętego wówczas przez Bułgarów. Sformułowanie to może wspierać interpretację, według której północne granice temu Tracji miały dochodzić do południowych stoków Hemosu ${ }^{20}$. Tak jednak mogło być wyłącznie w teorii, gdyż w rzeczywistości, poza pasem nadbrzeżnym, obszary pomiędzy Starą Płaniną a Strandżą, a nawet dalej na południe, były poza realnym zasięgiem władzy bizantyńskiej. Nie można też wykluczyć, że sugestia uczonego cesarza miała wyłącznie na celu podkreślenie praw cesarskich do całego terytorium Tracji Północnej, nie będąc odzwierciedleniem rzeczywistego stanu administracji państwa na tym obszarze. Realnie rzecz ujmując, aż do połowy VIII stulecia tem Tracji obejmował jedynie obszar Tracji Egejskiej i Północno-Wschodniej, przede wszystkim zaś pasy nadbrzeżne - egejski i czarnomorski ${ }^{21}$. W przypadku tego ostatniego, być może aż do południowych, nadbrzeżnych stoków Hemosu. Tam też, szczególnie gdy idzie o czarnomorskie wybrzeże Tracji najazdy barbarzyńskie przetrwało szereg ośrodków miejskich, zapewniających realną obecność władz bizantyńskich na tych terytoriach - utrzymywaną głównie za pośrednictwem akwenu morskiego, czyli z wykorzystaniem floty cesarskiej. Chodziło przede wszystkim o następujące miasta portowe - wymieniając kolejno z północy na południe - Mesembrię, Anchialos, Sozopol i Agatopol ${ }^{22}$.

Podobnie jak w przypadku temu trackiego, jednym z celów powstania temu Macedonii pomiędzy 789 a 802 r. było zorganizowanie skutecznej zapory przeciwko agresji ze strony Bułgarów. Siedzibą tej administracyjno-wojskowej jednostki był Adrianopol, a tem obejmował terytorium Tracji Północnej, a zatem obszaru z trzech stron zamkniętego masywami górskimi - Starej Płaniny wraz ze Sredną Gorą od północy i północnego zachodu, Rodopów od zachodu i południowego zachodu oraz Strandżą od południa ${ }^{23}$. Powstanie tej jednostki administracyjno-wojskowej sankcjo-

${ }^{20}$ Constantino Porfirogenito, De thematibus, 44, s. 84, 19 - 86, 61. Cf. rozważania u Г. Цанкова-Петкова, О територии болгарского государства в VII-IX вв., „Византийский Временник”, 1960 ,

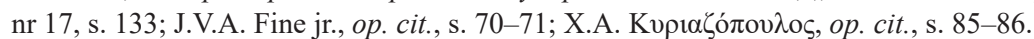

${ }^{21}$ Cf. П. Коледаров, Политическа география..., s. 8, 24; W. Treadgold, op. cit., s. 375; U. Fiedler, Bulgars in the Lower Danube region. A survey of the archaeological evidence and of the state of current research, w: The Other Europe in the Middle Ages. Avars, Bulgars, Khazars, and Cumans, red. F. Curta with the assistance of R. Kovalev, Leiden-Boston 2008, s. 153.

${ }^{22}$ Czyli dzisiejsze ośrodki bułgarskie - Nesebyr, Pomorie, Sozopol i Achtopol.

${ }^{23}$ Constantino Porfirogenito, De thematibus..., s. 162-166 (A. Pertusi); T. Wasilewski, Bizancjum ..., s. 27; Les listes de préséance..., loc. cit.; W. Swoboda, Tema..., s. 46; J.V.A. Fine jr., op. cit., s. 79-

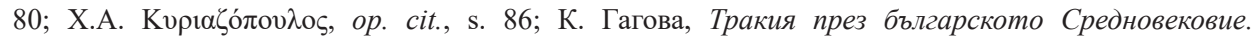
Историческа география, ${ }^{2}$ София 2002, s. 37; Corpus of Byzantine ..., s. 112-117 (nr 46-46.6.10-11.1415); Хр. Матанов, ор. cit., s. 31. П. Коледаров, Политическа география..., s. 31; idem, Образуване..., s. 222-223, zawęził okres powstania temu do lat 799-802. Podobnie P. Soustal, op. cit., s. 82. Błędna datacja jego powstania u В. Гюзелев, op. cit., s. 120. Tadeusz Wasilewski przyjął, że pierwotnie tem ten obejmował dolinę rzeki Strumy, a dopiero za czasów cesarza Leona V Armeńczyka (813-820) przeniesiony został na obszar północnej Tracji - T. Wasilewski, Bizancjum ..., s. 27, 58, 74-76. Podobną lokalizację (na wschód od doliny Strumy) przyjął również J. Koder, op. cit., s. 125. Oczywiście walka z Bułgarami 
nowało ostateczne odzyskanie terytoriów północnej Tracji, szczególnie zaś jej partii północno-zachodniej, przez władze w Konstantynopolu. Z kolei na obszarze geograficzno-historycznej Macedonii (jej południowo-wschodniej części), gdzieś pomiędzy połową a schyłkiem IX stulecia ustanowiono tem Strymonu (wzmiankowany pod rokiem 899 , podczas gdy w połowie tego wieku znana była strategia pod tą samą nazwą, a w VIII w. klisura), z siedzibą w Serres, obejmujący tereny pomiędzy rzekami Strymon i Nestos (dz. Struma i Mesta) na linii Zachód-Wschód oraz masywem Rodopów na północy i wybrzeżem egejskim na południu. Warren Treadgold uważa, że powstanie tej jednostki było wynikiem wymuszonej reorganizacji administracji cesarskiej na tym terenie, w związku z zakończeniem wojny bizantyńsko-bułgarskiej z lat 894-896 24 . Także dalej na zachodzie istniejące jednostki wojskowo-administracyjne, mianowicie temy Hellady (z siedzibą w Koryncie, a następnie Tebach) i Tesaloniki, pierwsza wzmiankowana jako strategia pod rokiem 695, druga ustanowiona w pierwszej ćwierci IX w. ${ }^{25}$, odgrywały ważną rolę w obronności i zachowaniu integralności terytoriów bizantyńskich w kontekście zagrożeń ze strony Bułgarii. Stacjonujący w nich żołnierze, wraz z pozostałymi cesarskimi oddziałami z obszaru

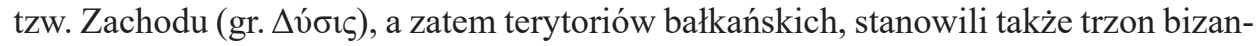
tyńskich sił ekspedycyjnych w trakcie wypraw na północnych sąsiadów.

Oczywiście tworzenie temów miało za zadanie przede wszystkim lepszą organizację administracji państwowej na danym terenie i zbudowanie skuteczniejszego systemu obrony terytoriów bizantyńskich. A zatem kwestia bułgarska nie była jedynym powodem tworzenia opisanego porządku administracyjnego, ale niewątpliwie w przypadku Tracji i Macedonii odgrywała istotną rolę. Wynikało to z faktu, że na obszarze północno-wschodnich Bałkanów to właśnie chanat bułgarski stanowił realne zagrożenie dla nowo odzyskanych terytoriów bizantyńskich. Można też pokusić się o stwierdzenie, że Bizancjum spieszyło się z odbudowaniem swojej potęgi na wskazanych terenach, chcąc uprzedzić Bułgarów przed ich ewentualnym podbiciem. System temowy sprzyjał realizacji tego planu. Oferował też silne zaplecze administracyjne dla fortyfikacji bizantyńskich wzniesionych na tych terytoriach. Innym niezwykle istotnym elementem wzmacniania pozycji bizantyńskich na omawianym terenie była realizowana przez wielu cesarzy polityka osadnicza, polegająca na zasiedlaniu Tracji i Macedonii ludnością sprowadzaną z innych obszarów cesarstwa, przede wszystkim zaś z terenów małoazjatyckich.

W kontekście relacji z Bułgarami Asparucha (681-695/701) prekursorem tego typu działań był cesarz Justynian II (685-695, 705-711), który wzmocnił bizantyńską obecność na nadmorskich obszarach Tracji Północnej sprowadzając do Mesembrii

nie była jedynym celem powstania wspomnianych jednostek administracyjnych - cf. В. Гюзелев, Княз Борис I. България през втората половина на IХ век, София 1969, s. 27.

${ }^{24}$ Constantino Porfirogenito, De thematibus..., s. 166-167 (A. Pertusi); Les listes de préséance...,

s. 101, 25; J.V.A. Fine jr., op. cit., s. 83; W. Treadgold, op. cit., s. 464; Corpus of Byzantine..., s. 159 (nr 73-73.1).

${ }^{25}$ Cf. Les listes de préséance..., s. 352; Corpus of Byzantine..., s. 83, 89, 91 ( $\mathrm{nr}$ 27, 34-34.1.6-7). 
osadników z Azji Mniejszej, wśród których znalazła się rodzina przyszłego cesarza Leona III (717-741) ${ }^{26}$. Pomijając inne aspekty tego zabiegu bizantyńskiego władcy warto zwrócić uwagę, że to miasto stanowiło ostatni bastion władzy cesarskiej na tym fragmencie wybrzeży trackich tuż przed przekroczeniem granicy z Bułgarią, która biegła wówczas południowymi stokami Starej Płaniny.

Realizując plan wzmocnienia pozycji cesarstwa na Bałkanach, Konstantyn V (741-775) w 755 lub 756 r. podjął się m.in. budowy oraz umacniania twierdz i mia-

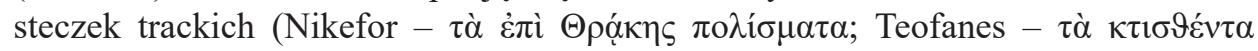
$\kappa \alpha ́ \sigma \tau \rho \alpha$ ), co przez potomnych uznane było za jedno z największych jego dokonań ${ }^{27}$. Fakt, iż wówczas już od trzydziestu lat między Bizancjum a Bułgarią panowały stosunki pokojowe, ustanowione na mocy trzydziestoletniego (jak się wydaje) pokoju z 716 r. $^{28}$, wskazuje, że ten manewr cesarza miał na celu m.in. przygotowanie odpowiedniego zaplecza infrastrukturalnego do planowanej przez niego ofensywy przeciwko Bułgarom ${ }^{29}$. Tracja musiała być również gotowa na przyjęcie ewentualnego odwetowego uderzenia nieprzyjaciela. Nie mniej istotnym, a nawet nadrzędnym, celem tych poczynań było rozlokowanie w strategicznie istotnych punktach omawianego obszaru umocnień, które gwarantowały nadzór i ochronę administracji cesarskiej nad zainicjowanym procesem zapełniania pustki osadniczej występującej na znacznych połaciach północnej Tracji ${ }^{30}$. W omawianych umocnieniach i wokół nich cesarz

26 Theophanis chronographia, AM 6209, s. 391, 5-10; Хр. Димитров, Славяни и прабългари по Западното Черноморско крайбрежие до края на IX век, „Годишник на Софийския Университет. Научен център за Славяно-византийски проучвания ,Ivan Dujčev"”, 1990/1991, nr 84/85 (4), s. 85.

${ }^{27}$ Nicephori Patriarchae Constantinopolitani breviarium historicum, 73, s. 144, 1-5; Theophanis chronographia, AM 6247, s. 429, 19-26; Nicephori archiepiscopi Constantinopolitani antirrhereticus tertius: Adversus Constantinum Copronymum, 73, w: PG, t. C, kol. 512 B-C; Georgii Monachii chronicon, wyd. C. de Boor, vol. II, Lipsiae 1904, s. 762, 25 - 763, 20. T. Wasilewski, Bizancjum ..., s. 31, 48, datuje początek wznoszenia twierdz na $752 \mathrm{r}$.

${ }^{28} \mathrm{O}$ nim vide Г. Цанкова-Петкова, Българо-византийският мирен договор от 716 г., w: Изследвания в чест на акад. Димитьр Дечев по случай на 80-годишнината му, red. В. Бешевлиев, В. Георгиев, София, 1958, s. 743-746; В. Кутиков, Българо-византийският договор от 7162. (Правно-историческо изследване), „Годишник на Софийския Университет. Юридически факултет”, 1974, nr 65.1, s. 69-119; N. Oikonomidès, Tribute or Trade? The Byzantine-Bulgarian Treaty of 716 , w: Studia Slavico-Byzantina et Mediaevalia Europensia. In memoriam Ivan Dujčev, t. I, red. P. Dinekov,

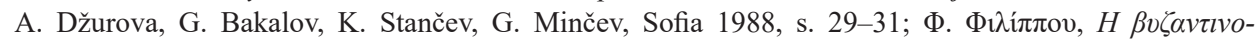

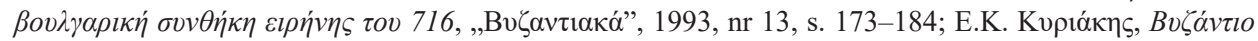

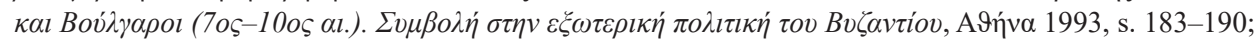
Г.Г. Литаврин, К дискусси о договоре 716 г. между Византией и Болгарией, w: idem, Византия и славяне..., s. 232-234; Ив. Билярски, Фискална система на средновековна България, Пловдив 2010, s. 131-139.

29 V. Beševliev, Die Protobulgarische Periode der bulgarischen Geschichte, Amsterdam 1981, s. 206207; Хр. Димитров, Константин V (741-775), w: Византийските василевси, red. Ив. Божилов, София 1997, s. 189. Przesiedleńcy ci mieli stanowić także zaporę przed najazdami bułgarskimi Д. Ангелов, Образуване на българската народност, ${ }^{2}$ София 1981, s. 209.

${ }^{30} \mathrm{O}$ niej vide R.-J. Lilie, ,,Thrakien“ und ,,Thrakesion“, ,Jahrbuch der Österreichischen byzantinistik”, 1977, nr 26, s. 7-47; П. Коледаров, Политическа география.., s. 8, 22, 24; Д. Ангелов, 
rozlokował bowiem Syryjczyków i Armeńczyków, sprowadzonych z Teodoziopola i Meliteny ${ }^{31}$. Z racji swego oddalenia od ziem ojczystych osadnicy ci byli szczególnie mocno związani z Konstantynopolem, co zapewniało ich lojalność. Osadzenie ludności bizantyńskiej na terenie Tracji mogło być również zabiegiem wycelowanym w ewentualnie występujące tu enklawy słowiańskie. Zwłaszcza, że władze bizantyńskie prowadziły też akcję wysiedlania tych ostatnich z Bałkanów na wschodnie krańce imperium ${ }^{32}$. A zatem działania przesiedleńcze realizowane były na obu kierunkach, w zależności od potrzeb państwa i powstałych zagrożeń militarnych. Wspomniane fortyfikacje miały więc pełnić rolę bezpiecznych baz dla przesiedleńców ze wschodu, a zatem ośrodków, z których rozchodzić się miała bizantyńska kolonizacja i rekonkwista.

Образуване..., s. 160; Р. Рашев, Поселищният живот в Северна Тракия през ранното Средновековие, w: Североизточна Тракия и Византия през IV-XIV век, red. Д. Овчаров, София-Сливен 1993, s. 103, 107-112; Д.В. Момчилов, Североизточна Тракия VII-X век, „Епохи”, 1995, nr 3.2, s. 61, 67; idem, Опит за демографска характеристика на Североизточна Тракия VII-X век, w: Проф. д.и.н. Станчо Ваклинов и средновековната българска култура, red. К. Попконстантинов, Б. Борисов, Р. Костова, Велико Търново 2005, s. 305-309; idem, Култура и политика на Първото българско иарство в Североизточна Тракия (по археологически данни), Варна 2007, s. 204-205, 217-219, 220; Б. Борисов, До тук стига България (Бележки по хронологията и развитието на селищната мрежа в Южсна България по времето на Първото българско иарство), w: Оттука започва България. Материали от втората национал- на конференция по история, археология и културен туризъм „Пътуване към България “- Шимен, 14-16.05.2010 година, red. Ив. Иорданов, Шумен 2011, s. 231251; К. Станев, Тракия през ранното Средновековие, Велико Търново 2012, s. 5-6, 53, 56-57, 174; Г.С. Грозданова, Населението на Южна България VI-IX в. (по археологически данни), София 2018, s. 42-50, 72-82, 133-164, szczególnie konkluzje na s. 164. Inaczej W. Swoboda, Tracja ..., s. 121-122.

${ }^{31}$ Nicephori Patriarchae Constantinopolitani breviarium historicum, 73, s. 144, 1-5; Theophanis chronographia, AM 6247, s. 429, 19-22; Nicephori archiepiscopi Constantinopolitani antirrhereticus tertius: Adversus Constantinum Copronymum, 72, kol. 509 A. Cf. również Theophanis chronographia, AM 6237, s. 422, 11-18. O etapach i chronologii sprowadzenia tych, jak i innych osadników z Azji Mniejszej, cf. m.in. P. Charanis, The Transfer of Population as a Policy in the Byzantine Empire, „Comparative Studies in Society and History”, 1961, nr 3.2, s. 144, 146, 151-152; T. Wasilewski, Bizancjum..., s. 45; Д. Ангелов, Образуване..., s. 208, 209; T. Wasilewski, Historia Butgarii, ${ }^{2}$ Wrocław 1988, s. 44; P. Soustal, op. cit., s. 79; H. Ditten, Umsiedlungen von Slawen aus Bulgarien nach Kleinasien einer und von Armeniern Syrern nach Thrakien andererseits zur Zeit des byzantinischen Kaisers Konstantin V. (Mitte des 8. Jhs), w: Bulgaria Pontica Medii Aevi, t. III, red. V. Gjuzelev, Sofija 1992, s. 25-42; idem, Ethnische Verschiebungen zwischen der Balkanhalbinsel und Kleinasien vom Ende des 6. bis zur Zweiten Hälfte des 9. Jahrhunderts, Berlin 1993, s. 68, 177-191 (najpełniej, też o innych przesiedleniach na teren Tracji); I. Rochow, Kaiser Konstantin V. (741-775). Materialien zu seinem Leben und Nachleben. Mit einem prosopographischen Anhung von Claudia Ludwig, Ilse Rochow und Ralph-Johannes Lilie, Frankfurt am Main 1994, s. 75-76, 91-92; Хр. Димитров, Константин V..., s. 189; W. Treadgold, op. cit., s. 359-

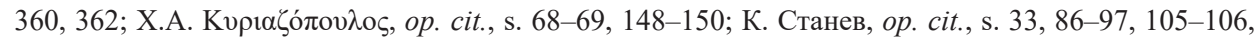
176.

32 Nicephori Patriarchae Constantinopolitani breviarium historicum, 38, s. 92, 1 - 94, 28; 75, s. 148, 1-5; Theophanis chronographia, AM 6180, s. 364, 11-15; AM 6254, s. 432, 27-29; M. Graebner, The Slavs in Byzantine population transfers of the Seventh and Eighth centuries, „Études Balkaniques”, 1975, nr 11.1, s. 40-52. 
Nie wiemy, które z twierdz i miast trackich wówczas umocniono i zasiedlono. Fakt, iż zaniepokoiło to Bułgarów na tyle, że zażądali od cesarza rekompensaty za te działania (przede wszystkim za budowę fortyfikacji), a po jego odmowie wyprawili się aż pod tzw. Długie Mury, dowodzi ${ }^{33}$, iż chodziło o ośrodki zagrażające Bułgarii, lub odbierane przez dwór bułgarski jako potencjalne dlań zagrożenie czy też naruszenie istniejącego status quo, zapewne utrwalonego powyżej wzmiankowanym porozumieniem pokojowym. Albo więc znajdowały się one niedaleko granicy między oboma państwami, albo też leżały na skraju terenu uznawanego za strefę buforową między chanatem a Bizancjum. Problem lokalizacji tych umocnień trudno rozwiązać, a sprowadza się on do określenia przebiegu ówczesnej granicy bizantyńsko-bułgarskiej. Jeżeli uznamy, że biegła ona wzdłuż głównej grani Hemosu lub jego południowych podnóży, to wśród tych umocnień mogła znajdować się również twierdza Markele (Markellai) ${ }^{34}$, po raz pierwszy wspomniana przez patriarchę Nikefora właśnie w związku z wydarzeniami 756 r. (lub 760 r.) ${ }^{35}$. Weselin Beszewliew założył hipotetycznie, że osadników tych rozlokowano zgodnie z przebiegiem granicy bizantyńsko-bułgarskiej za rządów chana Terweła, która według niego pokrywała się mniej więcej ze współczesną granicą bułgarsko-turecką ${ }^{36}$. Krasimira Gagowa wskazywała natomiast na tereny wokół Filipopola i Anchialos jako miejsce osadzenia przesie-

33 Nicephori Patriarchae Constantinopolitani breviarium historicum, 73, s. 144, 5-11; Theophanis chronographia, AM 6247, s. 429, 25-28; Nicephori archiepiscopi Constantinopolitani antirrhereticus tertius: Adversus Constantinum Copronymum, 72, kol. 509 A. V. Beševliev, Die Feldzüge des Kaisers Konstantin V. gegen die Bulgaren, w: idem, Bulgarisch-Byzantinische Aufsaetze, Aldershot 1978, s. 6 (nr XXXI); idem, Die Protobulgarische Periode..., s. 207, przyp. 14; idem, Една незабелязана кауза на българо-византийски мирен договор, „Годишник на Софийския Университет. Научен център за славяно-византийски проучвания ,Иван Дуйчев ”’, 1988, nr 82 (2), s. 8-9, dopuszcza, że w traktacie pokojowym między oboma państwami istniała klauzula zakazująca budowy umocnień na obszarze granicznym (podobnie S. Runciman, A History of the First Bulgarian Empire, London 1930, s. 35-36; J.V.A. Fine jr., op. cit., s. 76). Nie wyklucza, że mogła ona znajdować się w innym traktacie, przedłużającym trwanie pokoju z 716 r. - В. Бешевлиев, Три приноса към българската средновековна история, w: Изследвания в чест на Марин С. Дринов, red. А.К. Бурмов, Д. Ангелов, Ив. Дуйчев, София 1960, s. 287-288. Inni badacze uznają, że Bułgarzy zażądali zwyczajowego, corocznego trybutu, gwarantowanego wcześniejszymi porozumieniami - П. Мутафчиев, Лекции по история на Византия, t. II, red. Г. Бакалов, София 1995, s. 35-36; T. Wasilewski, Bizancjum ..., s. 45; Б. Примов, Г. Цанкова-Петкова, България през VIII в., w: История на България в четиринадесет тома, t. II, Първа българска държава, red. Д. Ангелов, София 1981, s. 120; F. Curta, Southeastern Europe in the Middle Ages 500-1250, Cambridge 2006, s. 8485. Kompromisową formułę zaproponowali П. Мутафчиев, История на българския народ /681-1323/, red. В. Гюзелев, София 1986, s. 121; Б. Примов, Г. Цанкова-Петкова, loc. cit., wedle których Bułgarzy zażądali zwyczajowego trybutu, powiększonego o dodatek za wzniesienie twierdz. J.V.A. Fine jr., op. cit., s. 76, oraz В. Гюзелев, Езическа България..., s. 114, stwierdził, że chan zażądał rekompensaty za wzniesienie twierdz, natomiast К. Гагова, op. cit., s. 34, uznała, że chan zażądał nowego układu pokojowego.

${ }^{34}$ Dzisiaj w odległości ok. 7 km na zachód od miasta Karnobat, w zachodniej partii wzniesienia Hisar będącego południową odnogą masywu Wschodniej Starej Płaniny.

${ }_{35}$ Nicephori Patriarchae Constantinopolitani breviarium historicum, 73, s. 144, 16-18.

${ }^{36}$ В. Бешевлиев, Една незабелязана кауза..., s. 9-10. Oczywiście po otrzymaniu przez chana Zagory. 
dleńców z Azji Mniejszej ${ }^{37}$. Dodam, że najprawdopodobniej rozlokowywano ich także w otwartych osadach wiejskich, właśnie w celu faktycznego zagospodarowywania tych terenów na rzecz Bizancjum, zwłaszcza, że północna Tracja należała do niewielu stosunkowo rozległych i żyznych obszarów bałkańskich nadających się pod uprawę rolną. Skądinąd wiadomo, że bizantyńska rekonkwista tych terytoriów dopiero się rozpoczynała, stąd nie można wykluczyć, że przynajmniej partie terenów pomiędzy Strandżą a Starą Płaniną stanowiły bufor dla obu państw, swoistą ziemię niczyją ${ }^{38}$.

Wobec powyższego, przyjmując hipotetycznie, że już w latach pięćdziesiątych VIII w. podjęto się umacniania Markele, wychodzę z założenia, że bizantyńskie panowanie na tym terenie miało charakter punktowy, tzn. koncentrowało się w kilku najistotniejszych ośrodkach miejskich, takich jak Filipopol, Anchialos i Mesembria oraz ich bezpośrednich okolicach. Zakładam tym samym, że tak bardzo wysunięty ku północy punkt jakim była Markele, pośrednio wskazuje, że to jednak południowe stoki masywu staropłanińskiego wyznaczały granicę chanatu bułgarskiego.

Działania Konstantyna V zmierzające do wzmocnienia pozycji Bizancjum w Tracji nie miały charakteru epizodycznego. Po powrocie do Konstantynopola z kolejnej wyprawy przeciwko Bułgarom wiosną 774 r. cesarz wysłat garnizony ze wszyst-

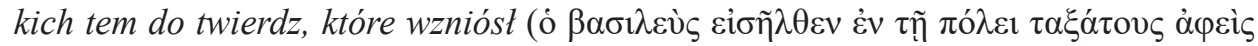

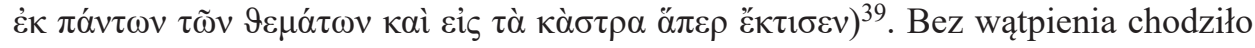
tutaj o te same nadgraniczne umocnienia, które cesarz nakazał wznieść lub odbudować w 755-756 r., choć nie można także wykluczyć, że wzięto tu pod uwagę jakieś nowe fortyfikacje, powstałe bliżej wzmiankowanej daty wysłania do nich odpowiednich garnizonów, jakkolwiek nie posiadamy twardych dowodów o kolejnych inwestycjach tego typu. Tekstu tego nie należy również rozumieć w sensie braku osadnictwa i oddziałów stacjonujących wewnątrz wzmiankowanych twierdz w przeciągu niemal dwudziestu lat od daty ich (przynajmniej części z nich) wzniesienia do czasu wzmiankowanej tu wyprawy. Źródła z epoki informują bowiem o użytkowaniu tychże (np. Markele i Anchialos) w czasie kampanii przeciwko Bułgarom w okresie tego niemal dwudziestolecia, a nie wydaje się, iż były to puste fortyfikacje, w których

${ }^{37}$ К. Гагова, ор. cit., s. 34. Cf. А. Данчева-Василева, Арменското присъствие в Пловдив през средновековието (VIII-ХIII в.), „Исторически преглед”, 1999, nr 55.5/6, s. 120.

38 П. Коледаров, Политическа география..., s. 6, 22; Д.В. Момчилов, Североизточна Тракия..., s. 62, 66. Jakkolwiek cesarstwo wysuwało zasadne, z punktu widzenia dawnej przynależności do Bizancjum Północnej Tracji, pretensje do tego terytorium.

39 Theophanis chronographia, AM 6265, s. 447, 8-9; tłum. - Testimonia najdawniejszych dziejów Stowian, z. 3, Pisarze z VII-X wieku, wyd. A. Brzóstkowska, W. Swoboda, Warszawa 1995, s. 66. Cf. Р. Рашев, Българо-византийският мир при Варна от 773 г., „История”, 1999, nr 7.2/3, s. 83. Posiadamy również świadectwa, które dowodzą, iż także pod koniec swoich rządów cesarz nadal kontynuował prace budowlane w Tracji. Były one pośrednio związane z wyprawami przeciwko Bułgarom. Chodzi tu o naprawę mostu na drodze łączącej Akradiopol z Wizą, w związku z szykowaną wyprawą pod Litosorię w końcu 774 r. - C. Mango, I. Ševčenko, Three Inscriptions of the Reigns of Anastasius I and Constantine V, „Byzantinische Zeitschrift”, 1972, nr 65.2, s. 384-393 (tekst i komentarz); P. Soustal, op. cit., s. 421. 
stacjonowały wyłącznie czasowo oddziały inwazyjne, w drodze do Bułgarii ${ }^{40}$. Takie swoiste refugia bądź bazy interwencyjne. Budowanie takich umocnień i to nadgranicznych, bez lokowania w nich stałych garnizonów kompletnie mijałoby się z sensem, narażając je na łatwe przejęcie przez wrogów, którzy wykorzystaliby je we własnych celach, np. jako przyczółki do działań na terenie Tracji Północnej. Wydaje się więc, że wyżej cytowana wzmianka donosi się do uzupełnienia garnizonów, które poniosły straty we wcześniejszych starciach z Bułgarami, gdy idzie o starsze twierdze, te wzniesione w połowie lat pięćdziesiątych VIII w., oraz wysłania oddziałów do fortyfikacji nowszej daty, w których takowych jeszcze nie było. Nie można też wykluczyć, że podjęte na polecenie Konstantyna $\mathrm{V}$ prace budowlane ciągnęły się przez dłuższy czas i sfinalizowano je dopiero w początkach lat siedemdziesiątych wspomnianego stulecia, dopiero wówczas wysyłając do nich odpowiednio silne jednostki zbrojne, które miały pełnić rolę stałych garnizonów. Jednak nawet w tym ostatnim przypadku inwestycje fortyfikacyjne podjęte w połowie lat pięćdziesiątych musiały być strzeżone przez odpowiednie, wystarczające do tego celu, jednostki militarne, choćby po to by realizować i nadzorować proces budowlany. Politykę przesiedleńczą swego ojca kontynuował również cesarz Leon IV (775-780), który w 778 r. przesiedlił do Tracji monofizyckich mieszkańców Syrii ${ }^{41}$.

Wizytacji i restauracji twierdz trackich zniszczonych w trakcie niedawnych wojen z Bułgarią podjęła się w maju 784 r. cesarzowa Irena wspólnie ze swym synem Konstantynem VI (780-797). Ten objazd po Tracji miał miejsce po udanej kampanii logotety Stauracjusza przeciwko plemionom słowiańskim. Przekazy źródłowe wprost stwierdzają, że z rozkazu władczyni towarzyszące jej wojsko odbudowało

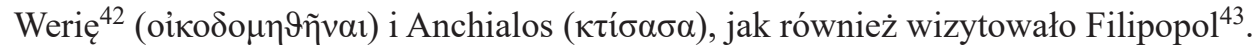

${ }^{40}$ Cf. Nicephori Patriarchae Constantinopolitani breviarium historicum, 73, s. 144, 16-18 (Markele, rok 756 lub 760); 76, s. 148, 11-12 (Anchialos, rok 763); 82, s. 156, 4-9 (Mesembria i Anchialos, rok 766); Theophanis chronographia, АM 6254, s. 433, 4-5 (Anchialos, rok 763); cf. Д. Момчилов, Ролята на Анхиало и Маркели при военните конфликти между България и Византия през периода на Първото българско ияарство, w: Великотърновският университет „Св. св. Кирил и Методий“ и българската археология, t. I, red. Б. Борисов, Велико Търново 2010, s. 437-438, 439, 440.

41 Theophanis chronographia, AM 6270, s. 451, 12 - 452, 2. Cf. Ioannis Scylitzae synopsis historiarum, 20, wyd. J. Thurn, Berolini et Novi Eboraci 1973, s. 276, 23 - 277, 27; P. Charanis, op. cit., s. 144; Д. Ангелов, Образуване..., s. 209; V. Beševliev, Die Protobulgarische Periode..., s. 229; Б. Примов, Г. Цанкова-Петкова, op. cit., s. 129; P. Soustal, op. cit., s. 81; H. Ditten, Ethnische Verschiebungen..., S. 192; R.-J. Lilie, Byzanz unter Eirene und Konstantin VI. (780-802). Mit einem Kapitel über Leon IV. (775-780) von Ilse Rochow, Frankfurt am Main 1996, s. 17, 21, 177 (tu także źródła arabskie); W. Treadgold, op. cit., s. 369; А. Данчева-Василева, loc. cit.; В. Гюзелев, Езическа България..., s. 120;

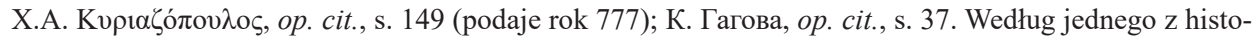
ryków armeńskich miało to być nawet 150000 .

42 Dz. Stara Zagora w Bułgarii.

${ }^{43}$ Ponieważ Teofanes nie wspomniał wprost o fortyfikowaniu Filipopola przyjąć należy, że rzeczywiście tego nie uczyniono - J.D. Howard-Johnston, Urban continuity in the Balkans in the early Middle Ages, w: Ancient Bulgaria. Papers presented to the International Symposium on the Ancient History and Archaeology of Bulgaria, University of Nottingham, część 2, red. A.G. Poulter, Nottingham 1983, s. 248. 
Pierwsza z wymienionych twierdz miała nawet zostać przemianowana na Irenopol. Miasta opasane zostały nowymi murami obronnymi lub naprawiono stare fortyfikacje. Odbudowano również ważny port anchialski. Był to nie tylko tryumfalny pochód manifestujący potęgę władzy cesarskiej na odzyskanych terytoriach ${ }^{44}$, lecz także zachęta skierowana $\mathrm{w}$ stronę dawnych, greckich osadników, by na nowo powrócili do tych ośrodków ${ }^{45}$.

Odbudowa i ponowne zasiedlenie tych miast miały szczególne znaczenie, gdyż wspomniane trzy umocnienia spełniały niezwykle istotną rolę w strategicznej obronie północnych obszarów trackich. Powyżej wspomniałem już, że Weria i Anchialos znajdowały się na północnym skraju terytorium górnotrackiego. Ta pierwsza twierdza leżała u wschodnich stoków Syrnenej Gory (czyli wschodniej odnogi Srednej Gory), ta druga zaś znajdowała się nad morzem. Obie zaś usytuowane były albo u podnóży centralnego Hemosu (Weria), albo też niedaleko południowych stoków jego wschodniej partii (Anchialos). W ten sposób fortyfikacje te kontrolowały peryferie nizinnych obszarów trackich. Dotyczyło to zwłaszcza podgórskiego szlaku komunikacyjnego prowadzącego z Sardyki nad Morze Czarne, biegnącego wzdłuż południowych podnóży wzmiankowanego masywu. Szlaku, na którym pomiędzy Sardyką i Werią na zachodzie a Mesembrią i Anchialos na wschodzie, także u południowych stoków

Innego zdania są R.-J. Lilie, op. cit., s. 174, oraz К. Гагова, op. cit., s. 268-269, którzy dopuszczają, że i w tym ośrodku doszło do napraw fortyfikacji. Natomiast Д. Ангелов, Образуване ..., s. 199-200, dodał także Mesembrię do miast, których mury obronne zostały wówczas odnowione, choć przekazy źródłowe w ogóle nie wspominają tego ośrodka.

${ }^{44}$ Możliwe, że po części również względem Bułgarii.

45 Szczególnie dotyczyło to wyludnionej Werii. Na temat poczynań Ireny w 784 r. - Theophanis chronographia, AM 6276, s. 457, 6-11; T. Wasilewski, Bizancjum..., s. 47; Б. Примов, Г. Цанкова-Петкова, loc. cit.; Д. Ангелов, Византия..., s. 149-150; J. Shepard, Slavs and Bulgars, w: The New Cambridge Medieval History, t. II: c. 700-c. 900, red. R. McKitterick, Cambridge 1995, s. 234; R.-J. Lilie, op. cit., s. 170, 173-174; W. Treadgold, op. cit., s. 418-419; К. Гагова, op. cit., s. 37; J. Herrin, Krwawe cesarzowe, przeł. Z. Simbierowicz, Warszawa 2006, s. 94-95 (z oczywistym błędem tłumacza, który poprawia poprawny wywód angielskiej uczonej, niesłusznie identyfikując źródłową Werię z noszącym tę samą nazwę ośrodkiem na terenie geograficzno-historycznej Macedonii). Nie ulega wątpliwości, że działania cesarzowej stanowiły propagandową manifestację, świadczącą o ponownym zaprowadzeniu na tych terytoriach pokoju przez władzę bizantyńską (Pax Byzantina). Sądzę, że aby podkreślić ten wymiar poczynań Ireny Teofanes posłużył się zarówno pewną grą słowną, jak i powtórzeniami. Tak więc napisał on o ce-

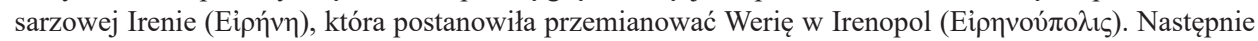
dotarła do Filipopola w pełnym bezpieczeństwie ( $\mu \varepsilon \tau \grave{\alpha} \pi \alpha ́ \sigma \eta \varsigma \dot{\alpha} \pi \alpha \vartheta \varepsilon i ́ \alpha \varsigma$ - inaczej: bez żadnych przeszkód)

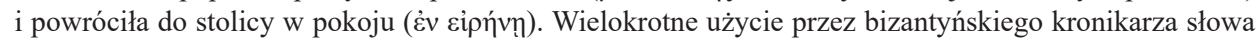

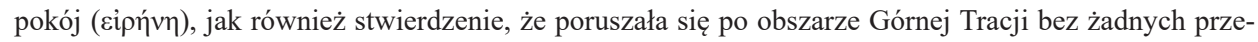
szkód, niewątpliwie miało za zadanie spotęgować u czytelnika wrażenie bezpieczeństwa zaprowadzonego w Tracji przez władzę w Konstantynopolu. W konstruowaniu powyższego obrazu Teofanesowi z pomocą przyszło imię samej cesarzowej, które idealnie nadawało się do poprowadzenia wspomnianej gry słownej. Reasumując, obszar północno-wschodniej Tracji był więc rzeczywiście bezpieczny, lub przynajmniej starano się stworzyć takie wrażenie - cf. uwagi R.-J. Lilie, op. cit., s. 171-179. Natomiast Jerzy Mnich wprost stwierdził, że do cesarskiego objazdu po Tracji doszło, gdy zapanował trwały pokój - Georgii

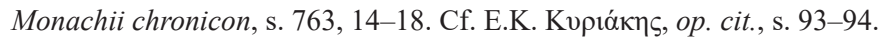


Hemosu (tu: Starej Płaniny) usytuowała była wspomniana twierdza Markele. Z drugiej strony omawiane umocnienia leżały na trasie kilku istotnych dróg przecinających pasmo górskie z północy na południe - Anchialos i Mesembria na drodze nadmorskiej (via pontica), która prowadziła do antycznego Odessos i tzw. Warny (rozumianej tu jako Jezioro Warneńskie i wpadającą doń rzekę Prowadijską wraz z jej dopływem czyli rzeką Dewnią, niewykluczone, że włącznie z terenami wokół nich) ${ }^{46}$, Weria zaś u wylotu przełęczy Zmejowskiej, czyli najdogodniejszej z dróg przechodzących przez pasmo srednogorskie, a dalej ku północy przez centralną partię masywu staropłanińskiego, zapewne przełęczami - Trewneńską czy Szipki. Ten ostatni ośrodek leżał również na trasie prowadzącej z Filipopola, wzdłuż południowych stoków Srednej Gory, do wspomnianej drogi u podnóży Starej Płaniny, a stąd do jej klisur. Filipopol z kolei, jak już powyżej wspomniałem, stanowił pierwsze ważne umocnione miasto na drodze militarnej, do którego docierało się po przekroczeniu Klisury Cesarskiej (a więc po opuszczeniu Hemosu). Z niego również można było wyruszyć na północ ku terytoriom bułgarskim, korzystając ze starożytnej drogi przecinającej oba masywy (staropłaniński poprzez Przełęcz Trojanską, zwaną również Trojan-Kyrnare) i docierającej na północy do starożytnego Oescus nad Dunajem ${ }^{47}$. Omawiane twierdze rozlokowane były zatem wzdłuż głównych szlaków komunikacyjnych na obszarze północnej Tracji - kontrolowały je i strzegły, zapewniając możliwie szybkie i dogodne przemieszczanie się po nich bizantyńskich oddziałów zbrojnych. Mogły stanowić również bazy wyjściowe do przeprawy przez Hemos i inwazję na terytorium chanatu bułgarskiego ${ }^{48}$. Z drugiej strony strzegły dostępu do systematycznie odzyskiwanych przez imperium obszarów trackich, jednym słowem miały uniemożliwić lub utrudnić Bułgarom atakowanie tych ziem i komplikowanie władzom bizantyńskim realizacji strategicznie istotnych zamierzeń, takich jak ustanowienie realnej i trwałej obecności administracji cesarskiej na tych terytoriach, a co za tym idzie ich rzeczywistej inkorporacji do Bizancjum. Na południu wszystkie omówione drogi lądowe ${ }^{49}$ zbiegały

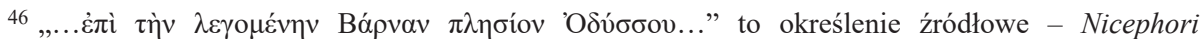
Patriarchae Constantinopolitani breviarium historicum, 36, s. 90, 19-20; Theophanis chronographia, AM 6171, s. 359, 8-9. Identyfikacja ze wskazanymi akwenami wodnymi opiera się na tekście Konstantyna VII Porfirogenety - Константин Багрянородный, Об управлении империей. Текст. Перевод. Коментарий, 9, red. Г.Г. Литаврин, А.П. Новосельцев, Москва 1991, s. 50, 100. Komentarz m.in. u В. Плетньов, П. Пеев, За средновековния варненски пристан Росо/Росито/Росико, w: Великотърновският Университет “Св. св. Кирил и Методий” и българската археология, red. Б. Борисов, t. I, Велико Търново 2010, s. 509-510.

47 Koło współczesnej miej. Gigen w Bułgarii.

48 В. Гюзелев, Езическа България..., s. 121-122, uznaje, że jednym z celów działań z 784 r. było przyszykowanie baz do natarcia na Bułgarię.

$49 \mathrm{Na}$ temat systemu drożnego w Tracji Północnej vide m.in. В. Тъпкова-Заимова, Към въпроса за военните пътища през Първото българско царство, „Исторически преглед”, 1958, nr 14.1, s. 5873; P. Soustal, op. cit., s. 132-146; K. Belke, Roads and travel in Macedonia and Thrace in the middle and late Byzantine period, w: Travel in the Byzantine World. Papers from the Thirty-fourth Spring Symposium of Byzantine Studies, Birmingham, April 2000, red. R. Macrides, Aldershot 2001, s. 73-90; A. Avramea, Land and Sea Communications, Fourth-Fiftheenth Centuries, w: The Economic History of Byzantium. 
się w Adrianopolu, który pełnił rolę strategicznego węzła komunikacyjnego dla całego tego obszaru. Wyruszając z niego w kierunku północnym, drogą wzdłuż doliny rzeki Tundży, można było dotrzeć do twierdzy Markele. Trasa pomiędzy tymi dwoma twierdzami wyznaczała centralną oś całego omawianego obszaru. Nie przypadkiem wkrótce to całe omawiane terytorium - Trację Północną - przekształcono w tem Macedonii ${ }^{50}$, co bez wątpienia dowodziło ustabilizowania się władzy cesarskiej na tym terenie.

Kolejni cesarze bizantyńscy kontynuowali politykę sprowadzania grup mieszkańców z Azji Mniejszej na tereny trackie. Niektórzy uczeni zakładają, że także w 790 r. doszło do przesiedlenia 12000 armeńskich kolonistów na obszar Tracji ${ }^{51}$. Natomiast działania podjęte w 784 r. realizował dalej Konstantyn VI podczas kampanii prze-

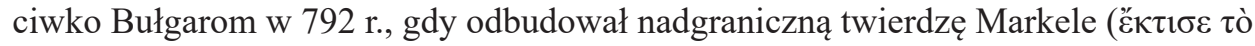

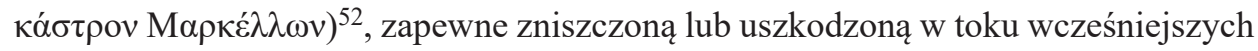
wojen bizantyńsko-bułgarskich z czasów Konstantyna V.

Nie jest wykluczone, że prace renowacyjne tego umocnienia i innych twierdz w Tracji północno-wschodniej trwały nadal jeszcze w 796 r. Pośrednio może wskazywać na to fakt, że chan Kardam (777-796/803) zażądał od cesarza trybutu ( $\pi \dot{\alpha} \kappa \tau \alpha)$. Jak zauważył W. Beszewliew greckie słowo $\pi \alpha ́ \kappa \tau \alpha$ zostało w tym fragmencie użyte przez Teofanesa bez rodzajnika określonego, co może dowodzić, że nie chodziło tu o zwyczajową należność, która przysługiwała Bułgarom na mocy jakiegoś wcześniejszego porozumienia ${ }^{53}$. Co prawda brak jest w przekazie Teofanesa informacji na

From the Seventh through the Fifteenth Century, red. A.E. Laiou, vol. I, Washington D.C. 2002, s. 64-74; К. Гагова, ор. cit., s. 99-110; М. Маджаров, Римският път Ескус - Филипопол. Пътни станции и селища, Пловдив 2004; J. Koder, op. cit., s. 91-99; П. Георгиев, Главният път Византия - България до края на VIII век, [in:] Пътуванията в средновековна България. Материали от първата национална конференичия "Пътуване към България. Пътуванията в средновековна България и съвременният туризъм”, Шумен, 8-11.05.2008 г., red. Ив. Йорданов, Велико Търново, 2009, s. 84-103; M. Madzharov, Roman Roads in Bulgaria. Contribution to the Development of Roman Road System in the Provinces of Moesia and Thrace, Veliko Tarnovo 2009; V. Tăpkova-Zaimova, Frontières médiévales et réseau routier au sud du Danube, „Bulgaria Mediaevalis”, 2010, nr 1, s. 1-15.

50 J. Shepard, op. cit., s. 234; J. Herrin, op. cit., s. 95.

51 Д. Ангелов, Образуване..., s. 209.

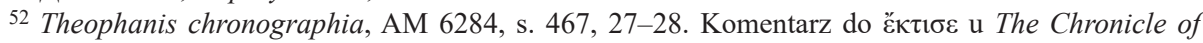
Theophanes Confessor. Byzantine and Near Eastern History AD 284-813, Translated with Introduction and Commentary by C. Mango and R. Scott with the assistance of G. Greatrex, Oxford 1997, s. 643, przyp. 4. Cf. V. Beševliev, Die Protobulgarische Periode..., s. 231; Д. Момчилов, Пътна и селищна система между Източна Стара Планина и „Еркесията” IV-XIV в. (Върбишки, Ришки и Айтоски проход), Варна 1999, s. 78. Pośrednim świadectwem zrujnowania twierdzy może być nieobecność jej biskupa na VII Soborze Ekumenicznym z 787 r. - T. Wasilewski, Bizancjum ..., s. 31. Niektórzy autorzy sądzą jednak, że Konstantyn VI nie odbudował twierdzy, lecz ją rozbudował - В. Гюзелев, Езическа България..., s. 122; Д. Момчилов, Култура и политика..., s. 39.

${ }^{53}$ V. Beševliev, Die Protobulgarische Periode..., s. 232. Inaczej interpretowali ten fragment m.in. П. Мутафчиев, История..., s. 130; G. Ostrogorski, Dzieje Bizancjum, red. H. Evert-Kappesowa, ${ }^{2}$ Warszawa 1968, s. 167, przyp. 97; T. Wasilewski, Bizancjum ..., s. 48; Б. Примов, Г. Цанкова-Петкова, op. cit.,

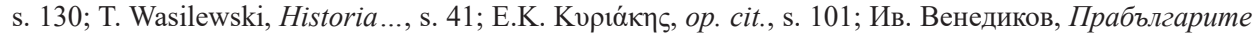


działalności restauracyjnej cesarza, lecz okoliczności wysunięcia żądań przez bułgarskiego władcę były niezwykle podobne do tych z roku 755-756, gdy Bułgarzy domagali się pieniężnej rekompensaty za budowę twierdz przez Konstantyna $\mathrm{V}^{54}$. Możliwa jest jednak inna interpretacja żądań Kardama. Otóż domagając się zapłaty trybutu chan pragnął jedynie wykorzystać coraz bardziej komplikującą się sytuację samego cesarza, przeciwko któremu zawiązała się silna opozycja na czele z Ireną, jego mat$\mathrm{ką}^{55}$. Innymi słowy, znając kłopoty Konstantyna VI zagroził mu, że dokona najazdu na Bizancjum, jeśli ten nie wypłaci mu żądanej sumy. Liczył przy tym, że znajdujący się w trudnej sytuacji cesarz łatwo ulegnie, aby zapewnić sobie spokój ze strony północnego sąsiada.

Akcje osadzania poddanych bizantyńskich na Bałkanach kontynuował także Nikefor I (802-811), który w roku 807 kazał pochwycić uchodźców i obcych z obszarów Azji Mniejszej i sprowadzić ich do Tracji, a w okresie 809-810 r. przesiedlił grupę ludności do tzw. Skalwinii na obszarze geograficznej Macedonii ${ }^{56}$. Dalszym krokiem w umacnianiu pozycji bizantyńskiej na obszarze wschodnich Bałkanów było włączenie twierdzy Sardyki w obręb cesarstwa, gdzieś u schyłku VIII stulecia. W ten sposób na przełomie VIII i IX w. Bizancjum zdołało stworzyć system fortyfikacji strzegący dostępu do nowo odzyskanych ziem cesarstwa i uniemożliwiający bułgarską ekspansję na południe ${ }^{57}$. Wśród wymienionych poniżej fortyfikacji wschodzących w skład tego systemu obronnego tylko kilka miało bezpośrednie znaczenie w działaniach zbrojnych na terenie Hemosu, a zatem na ówczesnej południowej granicy pań-

и християнството, Стара Загора 1998, s. 98; К. Гагова, op. cit., s. 37, według których chodziło właśnie o daninę zagwarantowaną traktatem pokojowym z 792 r. Podobnie R.-J. Lilie, op. cit., s. 184, który zwracał uwagę, że W. Beszewliew nie wziął pod uwagę możliwości opuszczenia rodzajnika przez kopistę. Ostatni pogląd jest jednak wyłącznie domysłem.

${ }^{54}$ Theophanis chronographia, AM 6247, s. 429, 19-28. Opisując tamte wydarzenia kronikarz także użył powyższego greckiego rzeczownika, również nie opatrując go rodzajnikiem.

${ }_{55}$ V. Beševliev, Die Protobulgarische Periode..., s. 233-234; E.K. Kvplóknৎ, op. cit., s. 95-97; R.-J. Lilie, op. cit., s. 87-99. Cf. П. Ангелов, Българската средновековна дипломаиия, София 1988, s. 87.

56 Theophanis chronographia, AM 6299, s. 482, 30 - 433, 2; AM 6302, s. 486, 10-19; P. Charanis, op. cit., s. 144-145; W. Swoboda, Nicefor I, w: Stownik Starożytności Stowiańskich. Encyklopedyczny zarys kultury Slowian od czasów najdawniejszych do schyłku wieku XII, t. III, $L-O$, red. W. Kowalenko, G. Labuda, Z. Stieber, Wrocław 1967, s. 371; Б. Примов, Укрепване и териториално разиирение на българската държава през първата половина на IX в., w: История на България в четиринадесет тома, t. II, Първа българска държава, red. Д. Ангелов, София 1981, s. 134; J.V.A. Fine jr., op. cit., s. 81-82, 95 (tu datacja drugiego z wymienionych przesiedleń na 810-811 r.); T. Wasilewski, Historia..., s. 48; Д. Ангелов, Византия..., s. 150-151; The Chronicle of Theophanes Confessor ..., s. 663, przyp. 1-2. Według J.V.A. Fine jr., op. cit., s. 81-82, 95; В. Гюзелев, Езическа България..., s. 128, kolonizacja z 810 r. objęła (według amerykańskiego badacza mogła objąć) także Sklawinie trackie, a celem jej było umocnienie pogranicza bizantyńsko-bułgarskiego.

57 T. Wasilewski, Bizancjum..., s. 49-50; idem, Historia..., s. 48; J. Shepard, op. cit., s. 235; В. Гюзелев, Езическа България..., s. 120-121. Nie chodziło rzecz jasna o to, że Bułgarzy nie mogli dokonywać łupieżczych najazdów na Macedonię, lecz o to, że pozostawienie za plecami takiej ważnej twierdzy czyniłoby wręcz niemożliwym trwałe opanowanie ziem macedońskich. 
stwa bułgarskiego. Inne rozsiane były w newralgicznych punktach centralnej partii północno-wschodnich Bałkanów. Najważniejszymi ośrodkami wchodzącymi w skład wspomnianego systemu defensywnego były twierdze Sardyka, Filipopol, Adrianopol, Dewelt $^{58}$, Weria, Markele, Mesembria i Anchialos. Jak już powyżej wskazałem łączyły je ze sobą dogodne szlaki komunikacyjne umożliwiające sprawne przerzucanie większych armii nad granicę z Bułgarią. Posiadały one także odpowiednie garnizony. $\mathrm{Z}$ powodu tego, że twierdze te znajdowały się na terytorium w pewnej mierze niezamieszkałym, z prawdopodobnie nielicznymi enklawami słowiańskimi, w ich okolicach koncentrowano przesiedleńców małoazjatyckich, co wydatnie wzmacniało polityczne i kulturalne wpływy bizantyńskie na tym terenie. Umocnienia te nie tylko stanowiły swoistą przeciwwagę dla bułgarskich (drewniano-ziemnych) urządzeń fortyfikacyjnych rozlokowanych w paśmie Hemosu ${ }^{59}$, lecz wykorzystywane były jako bizantyńskie bazy wypadowe przeciwko nim. Lokalizacja omawianych ośrodków wskazuje, że system twierdz obronnych rozlokowany był wzdłuż głównych arterii komunikacyjnych północno-wschodnich Bałkanów.

Przekazy źródłowe informują o tym, że również cesarz Leon V Armeńczyk odnowił miasta w Tracji i Macedonii znajdujące się nad granicą Bułgarami, tak aby uniemożliwiały im dokonywanie najazdów ${ }^{60}$. Działań tych podejmował się zarówno przed zawarciem pokoju z północnymi sąsiadami w 816 r. ${ }^{61}$, jak również i po jego

${ }^{58} \mathrm{Na}$ temat tego ośrodka cf. m.in. С. Дамянов, Археологическите открития в Дебелт, „Море”, 1982, nr 3.1, s. 234-241; idem, Проучвания в Дебелт - проблеми и перспективи, w: Странджанско-Сакарски сборник, t. II, część 2, Доклади от Втория интердисииплинарен симпозиум „СтранджаСакар”, Малко Търново 1980, Малко Търново 1984, s. 91-93; М. Балболова-Иванова, Девелт през VIII-Хвек, “Векове”, 1991, nr 20.1/2, s. 50-56; С. Дамянов, Таможный центр IХ в. в районе Дебелта. Предварительное сообщение, w: Bulgaria Pontica Medii Aevi, t. III, red. В. Гюзелев, София 1992, s. 247-251; Ch. Dimitrov, Die frühmittelalterliche Stadt Debeltos zwischen Byzanz und Bulgarien vom achten bis zehnte Jahrhundert, w: Die Schwarzmeerküste in der Spatantike und frühen Mittelalter, red. R. Pillinger, A. Pülz, H. Vetters, Wien 1992, s., s. 35-45; D. Sasselov, Die frühmittelalterlichen Mauern am Meer von Nessebăr, w: Bulgaria Pontica Medii Aevi, t. III, red. В. Гюзелев, София 1992, s. 227232; Ц. Дражева, Някои проблеми на градоустройственото развитие на Дебелт, „Известия на Националния исторически музей”, 2000, nr 11, s. 35-63; М. Балболова-Иванова, Средневековый Девелт в VIII-X вв., w: Bulgaria Pontica Medii Aevi, t. IV-V/1, red. В. Гюзелев, София 2003, s. 7984.

${ }^{59} \mathrm{O}$ nich, w szerszym kontekście zagadnienia, vide Р. Рашев, Землената укрепителна система на Първото българско ияарство, w: Плиска - Преслав, t. II, Прабългарската култура. Материали на българо-съветската срещз, Шумен 1976, red. Д. Ангелов, София 1981, s. 99-103; idem, Cmaробългарски укрепления на Долния Дунав /VII-XI в./, Варна 1982.

${ }^{60}$ Iosephi Genesii regum libri quattuor, I, 23, wyd. A. Lesmüeller-Werner, J. Thurn, Berolini 1978, s. 21, 35-38; Theophanis Continuati, I, 19, wyd. I. Bekker, Bonnae 1838, s. 30, 10-13. Cf. Scriptoris Incerti historia de Leone Barde Armenii filio, w: Leonis Grammatici Chronographia, wyd. I. Bekker, Bonnae 1842, s. 348, 2-11.

${ }^{61} \mathrm{Na}$ temat tego porozumienia pokojowego vide W. Treadgold, The Bulgars' Treaty with the Byzantines in 816, „Rivista di studi byzantini e slavi”, 1984, nr 4, s. 213-220. 
podpisaniu. Prace renowacyjne twierdz dokonywane były w ramach restytucji bizantyńskiej organizacji temowej na tych terenach ${ }^{62}$.

Posiadamy również informacje o wystawianiu bizantyńskich wojsk garnizonowych $(\tau \alpha \xi \alpha \tau i \tilde{\omega} v \alpha)$ w twierdzach Tracji i Macedonii za czasów cesarzowej Teodory. Dane te przytaczane są w związku z najazdami bułgarskimi na terytoria tych temów (być może w 850-851 r.). Te siły garnizonowe dokonywały odwetowych najazdów na twierdze i terytoria bułgarskie znajdujące się najprawdopodobniej za masywem strandżańskim, w północno-zachodniej Tracji ${ }^{63}$. Tradycyjnie znaczną część tych sił garnizonowych stanowili przesiedleńcy z Azji Mniejszej ${ }^{64}$.

$\mathrm{Z}$ kolei jedna $\mathrm{z}$ odnalezionych $\mathrm{w}$ Mesembrii inskrypcji bizantyńskich informuje o odbudowie tego ośrodka, zniszczonego wcześniej przez Bułgarów, przez cesarza Bazylego I (867-886) w okresie pomiędzy 879-886 r. Dane te potwierdzone zostały przez badania archeologiczne ${ }^{65}$. Trację, zrujnowaną w ciągu wieloletniego konfliktu z carem Symeonem I (893-927), cesarstwo zdołało odbudować w czasie pokojowej koegzystencji obu państw za rządów Piotra I (927-969), jego syna ${ }^{66}$. Również w czasie walk z Rusami w 970 r. cesarz Jan I Tzymiskes (969-976) rozlokowywał sprowadzone ze wschodu oddziały zbrojne na terenach bizantyńskich graniczących z Bułgarią. Miały one za zadanie strzec terytoriów cesarskich przed najazdami wojów Światosława i szpiegować poczynania wrogów ${ }^{67}$. W $971 \mathrm{r}$. sprowadził też do Tracji (w okolice Filipopola) kolejną grupę wschodnich osadników. Oni także mieli bronić Tracji przed najazdami koczowników przekraczających Hemos ${ }^{68}$. Podobnie postąpił Bazyli II (976-1025) w 988 lub 989 r., osadzając dużą liczbę Armeńczyków na obszarze temu macedońskiego ${ }^{69}$. Przy tej okazji słusznie zauważa się, że powyższe dzia-

62 T. Wasilewski, Bizancjum ..., s. 74; В. Гюзелев, Езическа България..., s. 146.

${ }^{63}$ Leonis Grammatici chronographia, wyd. Immanuel Bekker, Bonnae 1842, s. 235, 5-10. Cf. Georgii Monachii chronicon breve, V, 11, w: PG, t. CX, kol. 1044 C - 1045 A; Symeonis Magistri annales, 12, wyd. Immanuel Bekker, Bonnae 1838, s. 657, 7-11. Komentarz - Iv. Dujčev, A propos de la Vie de St. Pierre d'Atroa, „Byzantinoslavica”, 1966, nr 27.1, s. 92-97; T. Wasilewski, Bizancjum ..., s. 93, 98100; V. Beševliev, Die Protobulgarische Periode..., s. 296-297.

64 T. Wasilewski, Bizancjum..., s. 93, 98-99.

65 N. Oikonomidès, Mesembria in the Ninth Century: Epigraphical Evidence, w: idem, Byzantium from the Ninth Century to the Fourth Crusade. Studies, Texts. Monuments, Hampshire 1992, s. $272-273$.

66 В. Тъпкова-Заимова, Цар Петър. Вътрешно- и вънинополитическа дейност, w: История на България в четиринадесет тома, t. II, Първа българска държава, red. Д. Ангелов, София, 1981, s. 372 .

${ }^{67}$ Leonis Diaconi Caloënsis historiae libri decem, VI, 11, wyd. C.B. Hase, Bonnae 1828, s. 108, 9-17.

${ }^{68}$ Ioannis Scylitzae synopsis historiarum, 3, s. 286, 48-66; Annae Comnenae Alexias, wyd. D.R. Reinsch, A. Kambylis, t. I, Berolini et Novi Eboraci 2001, XIV, 8, 5-7, s. 455, 65 - 456, 74, 8391; Michaelis Glycae annales, IV, wyd. I. Bekker, Bonnae 1836, s. 623, 14-21; P. Charanis, op. cit., s. 146; П. Петров, Давид, Мойсей, Арон и Самуил начело на българската държава, w: История на България в четиринадесет тома, t. II, Първа българска държава, red. Д. Ангелов, София 1981, s. 400; J.V.A. Fine jr., op. cit., s. 188; А. Данчева-Василева, loc. cit.

69 P. Charanis, The Armenians in the Byzantine Empire, „Byzantinoslavica”, 1961, nr 22, s. 199; Д. Стоименов, Временна византийска военна администрация в българските земи (971-987/989), 
łania były praktykowane przez rząd bizantyński na najbardziej zagrożonych, pogranicznych obszarach państwa ${ }^{70}$. Kolejną falę, tym razem Serbów, przesiedlił w okolice Sardyki i do innych osad cesarz Manuel I Komnen (1143-1180) w 1149 r. ${ }^{71}$

Powyższy system fortyfikacji zachował swoją funkcjonalność także w okresach późniejszych. Analogie z XI-XII wieku dowodzą bowiem jego trwałości. Wskazują, że choć wówczas liczba ufortyfikowanych ośrodków zwiększyła się w stosunku do okresu wczesnośredniowiecznego, to ich zadania pozostały takie same. Anna Komnena wymienia z grubsza te same twierdze w związku z obroną Tracji przed najazdami azjatyckich koczowników. Wśród znanych już nam miast w jej dziele pojawiają się Sardyka, Filipopol, Adrianopol, Weria, Anchialos i Markele. Z nowych twierdz natomiast wymienia Nisos (Naissos), Petricz, Diampol, Lardeję i Goloe ${ }^{72}$. Podsumowując, stwierdzić należy, że bizantyńskie działania zmierzające do zabezpieczenia własnych terytoriów przed zagrożeniem ze strony Bułgarii biegły dwoma podstawowymi torami. Wznoszono i tworzono systemy fortyfikacji, których zadaniem było neutralizowanie bułgarskich umocnień pasma staropłanińskiego czy wrogiej ekspansji na południe. Nadto, starano się zwiększać liczebność bizantyńskich garnizonów twierdz nadgranicznych ${ }^{73}$. To wszystko realizowano $\mathrm{w}$ ramach stopniowo rozwijającego się systemu temowego, który odzwierciedlał postępy odzyskiwania dawnych ziem rzymskich na Bałkanach i miał za zadanie m.in. skuteczny nadzór nad realizacją założeń defensywnych i ofensywnych wobec naddunajskiego chanatu Bułgarów.

\section{BIBLIOGRAFIA}

\section{Źródla:}

Annae Comnenae Alexias, wyd. Diether R. Reinsch, Athanasios Kambylis, t. I, Berolini et Novi Eboraci 2001.

Constantino Porfirogenito, De thematibus, wyd. Agostino Pertusi, Città di Vaticano 1952.

„Годишник на Софийския Университет. Научен център за славяно-византийски проучвания „Иван Дуйчев"”, 1988, nr 82 (2), s. 55.

${ }^{70}$ П. Петров, loc. cit., który, pisząc o akcji przesiedleńczej Tzymiskesa z 971 r., niesłusznie uważał, że chodziło o powstrzymanie najazdów Komitopulów, gdyż w tym czasie nie doszło jeszcze do ich wystąpienia.

${ }^{71}$ Ioannis Cinnami epitome rerum ab Ioannae et Alexio Comnenis gestarum, III, 6, wyd. A. Meineke, Bonnae 1836, s. 103, 8-10; В.Н. Златарски, История на българската държава през средните векове, t. II, България под византийско владичество (1018-1187), София 1934, s. 388-389.

72 Vide m.in. Annae Comnenae Alexias, VII, 2, 1, s. 204, 38-47; VII, 2, 9-3, 1, s. 208, 62-70; VII, 3 , 12, s. 214, 50-55; VII, 4, 4, s. 216, 1-5; VII, 6, 1, s. 218, 50-51; VII, 6, 2, s. 218, 57-59; X, 2, 6, s. 286, $41-287,66$; X, 3, 1, s. 287, 84-1; X, 4, 10, s. 294, 21_24; X, 4, 11, s. 295, 48-51; XIV, 8, 1, s. 454, 16 24; XIV, 8, 5, s. 455, 65 - 456, 74; XIV, 8, 6-7, s. 456, 83-90. Petricz to dz. Petricz, Diampol - Jamboł, Lardeja i Goloe - trackie twierdze u podnóży i na południowych stokach Starej Płaniny, wszystkie zaś na terenie współczesnej Bułgarii - P. Soustal, op. cit., s. 239, 271, 333, 397-398.

73 Д.С. Овчаров, Византийски и български крепости V-Xвек, София 1982, s. 15; Д.В. Момчилов, Североизточна Тракия..., s. 61. 
Corpus of Byzantine Seals from Bulgaria, vol. I, Byzantine Seals with Geographical Names, ed. Ivan Jordanov, Sofia 2003.

Georgii Monachii chronicon breve, w: PG, t. CX, kol. 1035-1286.

Georgii Monachii chronicon, wyd. Carl de Boor, vol. II, Lipsiae 1904.

Ioannis Cinnami epitome rerum ab Ioannae et Alexio Comnenis gestarum, wyd. August Meineke, Bonnae 1836.

Ioannis Scylitzae synopsis historiarum, wyd. Johannes Thurn, Berolini et Novi Eboraci 1973.

Iosephi Genesii regum libri quattuor, wyd. Anni Lesmüeller-Werner, Johannes Thurn, Berolini 1978.

Jordanov Ivan, Pečatite ot strategijata v Preslav (971-1088), Sofija, 1993 [Йорданов Иван, Печатите от стратегията в Преслав (971-1088), София, 1993].

Konstantin Bargjanorodnyj, Ob upravlenii imperiej. Tekst. Perevod. Komentarij, red. Genadij Grigorijevič Litavrin, Anatolij Petrovič Novosel'cev, Moskva 1991 [Константин Багрянородный, Об управлении империей. Текст. Перевод. Коментарий, red. Геннадий Григорьевич Литаврин, Анатолий Петррович Новосельцев, Москва 1991].

Leonis Diaconi Caloënsis historiae libri decem, wyd. Karl Benedikt Hase, Bonnae 1828.

Leonis Grammatici chronographia, wyd. Immanuel Bekker, Bonnae 1842.

Les listes de préséance byzantines des IXe et $X^{e}$ siècles, wyd. Nicolas Oikonomidès, Paris 1972.

Michaelis Glycae annales, wyd. Immanuel Bekker, Bonnae 1836.

Nicephori archiepiscopi Constantinopolitani antirrhereticus tertius: Adversus Constantinum Copronymum, w: $P G$, t. C, kol. 375-534.

Nicephori Patriarchae Constantinopolitani breviarium historicum, wyd. Cyril Mango, Washingtoniae D.C. 1990.

Testimonia najdawniejszych dziejów Słowian, z. 3, Pisarze z VII-X wieku, wyd. Alina Brzóstkowska, Wincenty Swoboda,, Warszawa 1995.

Scriptoris Incerti historia de Leone Barde Armenii filio, w: Leonis Grammatici Chronographia, wyd. Immanuel Bekker, Bonnae 1842, s. 333-362.

Symeonis Magistri annales, wyd. Immanuel Bekker, Bonnae 1838.

The Chronicle of Theophanes Confessor. Byzantine and Near Eastern History AD 284-813, Translated with Introduction and Commentary by Cyril Mango and Robert Scott with the assistance of Geoffrey Greatrex, Oxford 1997.

Theophanis chronographia, wyd. Carl de Boor, t. I, Lipsiae 1883.

Theophanis Continuati, wyd. Immanuel Bekker, Bonnae 1838.

\section{Literatura:}

Angelov Dimităr, Obrazuvane na bălgarskata narodnost, ${ }^{2}$ Sofija, 1981 [Ангелов Димитьр, Образуване на българската народност, ${ }^{2}$ София, 1981].

Angelov Dimităr, Vizantija. Văzchod i zalez na edna imperija, Sofija, 1991 [Ангелов Димитър, Византия. Възход и залез на една империя, София, 1991].

Angelov Petăr, Bălgarskata srednovekovna diplomacija, Sofija, 1988 [Ангелов Петър, Българската средновековна дипломаиия, София, 1988].

Avramea Anna, Land and Sea Communications, Fourth-Fiftheenth Centuries, w: The Economic History of Byzantium. From the Seventh through the Fifteenth Century, red. Angeliki E. Laiou, vol. I, Washington D.C. 2002, s. 64-74.

Balbolova-Ivanova Marija, Develt prez VIII-X vek, "Vekove", 1991, nr 20.1/2, s. 50-56 [Балболова-Иванова Мария, Девелт през VIII-X век, "Векове”, 1991, nr 20.1/2, s. 50-56].

Balbolova-Ivanova Marija, Srednevekovyj Develt v VIII-Xvv., w: Bulgaria Pontica Medii Aevi, t. IV-V/1, red. Vasil Gjuzele, Sofija, 2003, s. 79-84 [Балболова-Иванова Мария, Средневековый Девелт в VIII-X вв., w: Bulgaria Pontica Medii Aevi, t. IV-V/1, red. Васил Гюзелев, София 2003, s. 79 84].

Belke Klaus, Roads and travel in Macedonia and Thrace in the middle and late Byzantine period, $\mathrm{w}$ : Travel in the Byzantine World. Papers from the Thirty-fourth Spring Symposium of Byzantine Studies, Birmingham, April 2000, red. Ruth Macrides, Aldershot 2001, s. 73-90. 
Beševliev Veselin, Die Feldzüge des Kaisers Konstantin V. gegen die Bulgaren, w: idem, Bulgarisch-Byzantinische Aufsaetze, Aldershot 1978, s. 5-17 (nr XXXI).

Beševliev Veselin, Die Protobulgarische Periode der bulgarischen Geschichte, Amsterdam 1981.

Beševliev Veselin, Edna nezabeljazana klauza na bălgaro-vizantijski miren dogovor, „Godišnik na Sofijskija Universitet. Naučen centăr za slavjano-vizantijski proučvanija ,Ivan Dujčev"”, 1988, nr 82 (2), s. 7-10 [Бешевлиев Веселин, Една незабелязана кауза на българо-византийски мирен договор, „Годишник на Софийския Университет. Научен център за славяно-византийски проучвания ,Иван Дуйчев””, 1988, nr 82 (2), s. 7-10].

Beševliev Veselin, Tri prinosa kăm bălgarskata srednovekovna istorija, w: Izsledvanija v čest na Marin S. Drinov, red. Aleksandăr K. Burmov, Dimităr Angelov, Ivan Dujčev, Sofija, 1960, s. 283-300 [Бешевлиев Веселин, Три приноса към българската средновековна история, w: Изследвания 8 чест на Марин С. Дринов, red. Васил Гюзелев, София, 1960, s. 283-300].

Biljarski Ivan., Fiskalna sistema na srednovekovna Bălgarija, Plovdiv, 2010 [Билярски Иван, Фискална система на средновековна България, Пловдив, 2010].

Borislav Primov, Ukrepvane i teritorialno razširenie na bălgarskata dăržava prez părvata polovina na IX v., w: Istorija na Bălgarija v četirinadeset toma, t. II, Părva bălgarska dăržava, red. Dimităr Angelov, Sofija, 1981, s. 130-161 [Примов Борислав, Укрепване и териториално разиирение на българската държава през първата половина на IX в., w: История на България в четиринадесет тома, t. II, Първа българска държава, red. Димитър Ангелов, София, 1981, s. 130-161].

Borisov Boris, Do tuk stiga Bălgarija (Beležki po chronologijata i razvitieto na selištnata mreža v Južna Bălgarija po vremeto na Părvoto bălgarsko carstvo), w: Ottuka započva Bălgarija. Materiali ot vtorata nacionalna konferencija po istorija, archeologija $i$ kulturen turizăm „Pătuvane kăm Bălgarija” - Šumen, 14-16.05.2010 godina, red. Ivan Jordanov, Šumen, 2011, s. 231-251 [Борисов Борис, До тук стига България (Бележки по хронологията и развитието на селищната мрежа в Южна България по времето на Първото българско ияарство), w: Оттука започва България. Материали от втората начионална конференция по история, археология и културен туризъм „Пътуване към България “- Шимен, 14-16.05.2010 година, red. Иван Йорданов, Шумен, 2011, s. 231-251].

Cankova-Petkova Genoveva, Bălgaro-vizantijskijat miren dogovor ot 716 g., w: Izsledvanija v čest na akad. Dimităr Dečev po slučaj na 80-godišninata mu, red. Veselin Beševliev, Vladimir Georgiev, Sofija, 1958, s. 743-746 [Цанкова-Петкова Геновева, Българо-византийският мирен договор от 716 г., w: Изследвания в чест на акад. Димитър Дечев по случай на 80-годишнината му, red. Веселин Бешевлиев, Владимир Георгиев, София, 1958, s. 743-746].

Cankova-Petkova Genoveva, O teritorii bolgarskogo gosudarstva v VII-IX vv., „Vizantijskij Vremennik”, 1960, nr 17, s. 124-143 [Цанкова-Петкова Геновева, О територии болгарского государства в VII-IX вв., „Византийский Временник”, 1960, nr 17, s. 124-143].

Charanis Peter, The Armenians in the Byzantine Empire, „Byzantinoslavica”, 1961, nr 22, s. 196-240.

Charanis Peter, The Transfer of Population as a Policy in the Byzantine Empire, „Comparative Studies in Society and History", 1961, nr 3.2, s. 140-154.

Croke Brian, Count Marcellinus and his Chronicle, Oxford 2001.

Curta Florin, Southeastern Europe in the Middle Ages 500-1250, Cambridge 2006.

Czeppe Zdzisław, Flis Jan, Mochnacki Rodion, Geografia fizyczna świata, Warszawa 1969.

Damjanov Stefan, Archeologičeskite otkritija v Debelt, „More”, 1982, nr 3.1, s. 234-241 [Дамянов Стефан, Археологическите открития в Дебелт, „Море”, 1982, nr 3.1, s. 234-241].

Damjanov Stefan, Proučvanija v Debelt - problemi i perspektivi, w: Strandžansko-Sakarski sbornik, t. II, część 2, Dokladi ot Vtorija interdisciplinaren simpozium ,Strandža-Sakar”, Malko Tărnovo 1980, Malko Tărnovo, 1984, s. 91-93 [Дамянов Стефан, Проучвания в Дебелт - проблеми и перспективи, w: Странджанско-Сакарски сборник, t. II, część 2, Доклади от Втория интердисциплинарен симпозиум „Странджа-Сакар”, Малко Търново 1980, Малко Търново 1984, s. 91-93].

Damjanov Stefan, Tamožnyj centr IXv. v rajone Debelta. Predvaritel'noe soobšenie, w: Bulgaria Pontica Medii Aevi, t. III, red. Vasil Gjuzelev, Sofija, 1992, s. 247-251 [Дамянов Стефан, Таможный цен- 
тр IX в. в районе Дебелта. Предварительное сообщение, w: Bulgaria Pontica Medii Aevi, t. III, red. Васил Гюзелев, София, 1992, s. 247-251].

Dančeva-Vasileva Ani, Armenskoto prisăstvie v Plovdiv prez srednovekovieto (VIII-XIII v.), „Istoričeski pregled", 1999, nr 55.5/6, s. 119-135 [Данчева-Василева Ани, Арменското присъствие в Пловдив през средновековието (VIII-ХIII в.), „Исторически преглед”, 1999, nr 55.5/6, s. 119-135].

Danov Georgi D., Sredna Gora. Pătevoditel, Sofija 1971 [Данов Георги Д., Средна Гора. Пътеводител, София 1971].

Dimitrov Christo, Die frühmittelalterliche Stadt Debeltos zwischen Byzanz und Bulgarien vom achten bis zehnte Jahrhundert, w: Die Schwarzmeerküste in der Spatantike und frühen Mittelalter, red. Renate Pillinger, Andreas Pülz, Hermann Vetters, Wien 1992, s. 35-45.

Dimitrov Christo, Konstantin V (741-775), w: Vizantijskite vasilevsi, red. Ivan Božilov, Sofija, 1997, s. 188-193 [Димитров Христо, Константин V (741-775), w: Византийските василевси, red. Иван Божилов, София, 1997, s. 188-193].

Dimitrov Christo, Slavjani i prabălgari po Zapadnoto Černomorsko krajbrežie do kraja na IX vek, „Godišnik na Sofijskija Universitet. Naučen Centăr za Slavjano-vizantijski proučvanija ,Ivan Dujčev"”, 1990/1991, nr 84/85 (4), s. 79-100 [Димитров Христо, Славяни и прабългари по Западното Черноморско крайбрежие до края на IX век, „Годишник на Софийския Университет. Научен център за Славяно-византийски проучвания „Иван Дуйчев””, 1990/1991, nr 84/85 (4), s. 79-100].

Ditten Hans, Ethnische Verschiebungen zwischen der Balkanhalbinsel und Kleinasien vom Ende des 6. bis zur Zweiten Hälfte des 9. Jahrhunderts, Berlin 1993.

Ditten Hans, Umsiedlungen von Slawen aus Bulgarien nach Kleinasien einer - und von Armeniern Syrern nach Thrakien andererseits zur Zeit des byzantinischen Kaisers Konstantin V. (Mitte des 8. Jhs), w: Bulgaria Pontica Medii Aevi, t. III, red. Vasil Gjuzelev, Sofija 1992, s. 25-42.

Draževa Conja, Njakoi problemi na gradoustrojstvenoto razvitie na Debelt, „Izvestija na Nacionalnija istoričeski muzej”, 2000, nr 11, s. 35-63 [Дражева Цоня, Някои проблеми на градоустройственото развитие на Дебелт, „Известия на Националния исторически музей”, 2000, nr 11, s. 3563].

Dujčev Ivan, A propos de la Vie de St. Pierre d'Atroa, „Byzantinoslavica”, 1966, nr 27.1, s. 92-97.

Fiedler Uwe, Bulgars in the Lower Danube region. A survey of the archaeological evidence and of the state of current research, w: The Other Europe in the Middle Ages. Avars, Bulgars, Khazars, and Cumans, red. Florin Curta with the assistance of Roman Kovalev, Leiden-Boston 2008, s. 152-236.

Filippou Filippos, E bydzantino-boulgarike syntheke eirenes tou 716, „Byzantiaka”, 1993, nr 13, s. 173-

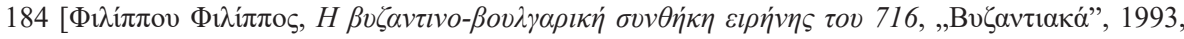
nr 13, s. 173-184].

Fine jr. John Van Antwerp, The Early Medieval Balkans. A Critical Survey from the Sixth Century to the Late Twelfth Century, Ann Arbor 1983.

Gagova Krasimira, Trakija prez bălgarskoto Srednovekovie. Istoričeska geografija, ${ }^{2}$ Sofija, 2002 [Гагова Красимира, Тракия през българското Средновековие. Историческа география, ${ }^{2}$ София, 2002].

Georgiev Pavel, Glavnijat păt Vizantija - Bălgarija do kraja na VIII vek, w: Pătuvanijata v srednovekovna Bălgarija. Materiali ot părvata nacionalna konferencija "Pătuvane kăm Bălgarija. Pătuvanijata v srednovekovna Bălgarija i săvremennijat turizăm”, Šumen, 8-11.05.2008 g., red. Ivan Jordanov, Veliko Tărnovo, 2009, s. 84-103 [Георгиев Павел, Главният път Византия - България до края на VIII век, w: Пътуванията в средновековна България. Материали от първата национална конференция "Пътуване към България. Пътуванията в средновековна България и съвременният туризъм”, Шумен, 8-11.05.2008 г, red. Иван Йорданов, Велико Търново, 2009, s. 84-103].

Gjuzelev Vasil, Ezičeska Bălgarija, w: Ivan Božilov, Vasil Gjuzelev, Istorija na srednovekovna Bălgarija VII-XIV vek, Sofija, 1999, s. 55-166 [Гюзелев Васил, Езическа България, w: Иван Божилов, Васил Гюзелев, История на средновековна България VII-XIV век, София, 1999].

Gjuzelev Vasil, Knjaz Boris I. Bălgarija prez vtorata polovina na IX vek, Sofija, 1969 [Гюзелев Васил, Княз Борис I. България през втората половина на IX век, София, 1969]. 
Graebner Michael, The Slavs in Byzantine population transfers of the Seventh and Eighth centuries, „Études Balkaniques”, 1975, nr 11.1, s. 40-52.

Grozdanova Galina Stefanova, Naselenieto na Južna Bălgarija VI-IX v. (po archeologičeski danni), Sofija, 2018 [Грозданова Галина Стефанова, Населението на Южна България VI-IX в. (nо археологически данни), София, 2018].

Haarer Fiona, Anastasius I: Politics and Empire in the Late Roman world, Cambridge, 2006.

Herrin Judith, Krwawe cesarzowe, przeł. Zygmunt Simbierowicz, Warszawa 2006.

Howard-Johnston James Douglas, Urban continuity in the Balkans in the early Middle Ages, w: Ancient Bulgaria. Papers presented to the International Symposium on the Ancient History and Archaeology of Bulgaria, University of Nottingham, część 2, red. Andrew Graham Poulte, Nottingham 1983, s. $242-254$.

Irmscher Johannes, Die Begründung des Themas Thrake, „Studia Balcanica”, 1975, nr 10, s. 101-103.

Jireček Konstantin Josef, Die Heerstrasse von Belgrad nach Constantinopel und die Balkanpässe. Eine Historisch-Geographische Studie, Prag 1877.

Karajotov Ivan, Antičnijat Deultum, srednovekovnijat Debelt, „More”, 21, 2000, 1-2, s. 7-10 [Карайотов Иван, Античният Деултум, средновековният Дебелт, „Море”, 21, 2000, 1-2, s. 7-10].

Keckarov Vasil, Ukrepitelnata organizacja na Bălgarija i na Vizantija ot VII do IX veka, „Rodina”, 1940, nr 2.3, s. 38-52 [Кецкаров Васил, Укрепителната организация на България и Византия от VII до IX века, „Родина”, 1940, nr 2.3, s. 38-52].

Kelly Christopher, Attila the Hun: Barbarian terror and the fall of the Roman Empire, London 2008.

Kiradžiev Svetlin, Enciklopedičen geografski rečnik na Bălgarija, ${ }^{2}$ Sofija 2013 [Кираджиев Свелтин, Енциклопедичен географски речник на България, ${ }^{2}$ София 2013].

Koder Johannes, To Bydzantio os choros. Eisagoge sten Istorike Geografia tes Anatolikes Mesogeiou ste Bydzantine Epoche, thum. Dionysios Ch. Stathakopoulos, Thessalonike, 2005 [Koder Johannes, To

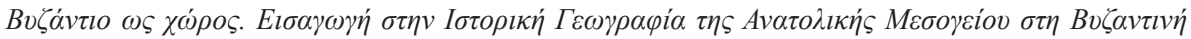

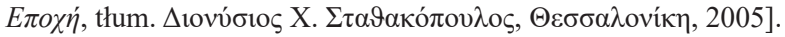

Koledarov Petăr Stojanov, Obrazuvane na tema „Makedonija” v Trakija, „Izvestija na Instituta za istorija“, 21, 1979, s. 219-243 [Коледаров Петър Стоянов, Образуване на тема „Македония” в Тракия, „Известия на Института за история”, 1979, nr 21, s. 219-243].

Koledarov Petăr, Političeska geografija na srednovekovnata bălgarska dăržava, t. I, Ot 681 do 1018 g., Sofija, 1979 [Коледаров Петър, Политическа география на средновековната българска държава, t. I, От 681 до 1018 г., София, 1979].

Kurnatowska Zofia, Stowiańszczyzna Południowa, Wrocław-Warszawa-Kraków-Gdańsk 1977.

Kutikov Vladimir, Bălgaro-vizantijskijat dogovor ot 716 g. (Pravno-istoričesko izsledvane), „Godišnik na Sofijskija Universitet. Juridičeski fakultet”, 1974, nr 65.1, s. 69-119 [Кутиков Владимир, Българо-византийският договор от 716 г. (Правно-историческо изследване), „Годишник на Софийския Университет. Юридически факултет”, 1974, nr 65.1, s. 69-119].

Kyriadzopoulos Christos A., E Thrake kata tous $10^{\circ}-12^{\circ}$ aiones. Symbole ste melete tes politikes, dio-

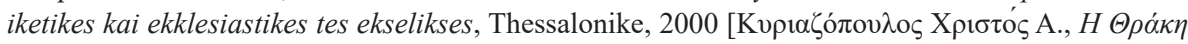

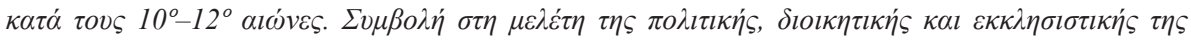
$\varepsilon \xi \varepsilon \lambda i \xi \eta \xi,, \Theta \varepsilon \sigma \sigma \alpha \lambda o v i ́ \kappa \eta, 2000]$.

Kyriakes Euangelos K., Bydzantio kai Boulgaroi (7os-10os ai.). Symbole sten eksoterike politike tou

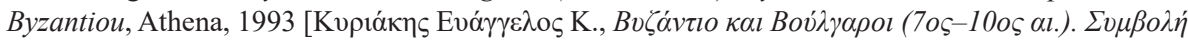

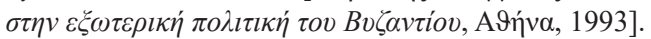

Leontsine Maria, Konstantinos IV (668-685). O teleutaios protobydzantinos autokratoras, Athena, 2006

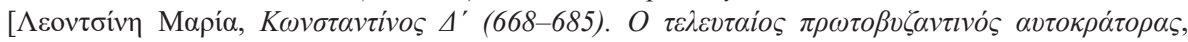
AЭńva, 2006].

Liebeschuetz John Hugo Wolfgang Gideon, The Lower Danube region under pressure: from Valens to Heraclius, w: The transition to Late Antiquity: on the Danube and beyond, red. Andrew Poulter, Oxford 2007, s. 101-134.

Lilie Ralph-Johannes, Byzanz unter Eirene und Konstantin VI. (780-802). Mit einem Kapitel über Leon IV. (775-780) von Ilse Rochow, Frankfurt am Main 1996. 
Lilie Ralph-Johannes, ,,Thrakien“ und „Thrakesion“, „Jahrbuch der Österreichischen byzantinistik”, 1977 , nr 26, s. 7-47.

Litavrin Gennedij Grigorijevič, $K$ diskussii o dogovore 716 g. meždu Vizantiej i Bolgariej, w: idem, Vizantija i slavjane (sbornik statej), Sankt-Peterburg, 1999, s. 232-234 [Литаврин Геннадий Григорьевич, К дискусси о договоре 716 г. между Византией и Болгарией, w: idem, Византия и славяне (сборник статей), Санкт-Петербург, 1999, s. 232-234].

Litavrin Gennedij Grigorijevič, K probleme stanovlenija bolgarskogo gosudarstva, w: idem, Vizantija i slavjane (sbornik statej), Sankt-Peterburg, 1999, s. 192-217 [Литаврин Геннадий Григорьевич, К проблеме становления болгарского государства, w: idem, Византия и славяне (сборник статей), Санкт-Петербург, 1999, s. 192-217].

Madžarov Mitko, Rimskijat păt Eskus - Filipopol. Pătni stancii i selišta, Plovdiv, 2004 [Маджаров Митко, Римският път Ескус - Филипопол. Пътни станции и селища, Пловдив, 2004].

Madžarov Mitko, Roman Roads in Bulgaria. Contribution to the Development of Roman Road System in the Provinces of Moesia and Thrace, Veliko Tarnovo 2009.

Mango Cyril, Ševčenko Ihor, Three Inscriptions of the Reigns of Anastasius I and Constantine V, „Byzantinische Zeitschrift", 1972, nr 65.2, s. 379-393.

Marinow Kirił, The Haemus Mountains and the Geopolitics of the First Bulgarian Empire: An Overview, “Зборник радова Византолошког института”, 2014, nr 51, s. 17-32.

Maruszczak Henryk, Butgaria, Warszawa 1971.

Matanov Christo, Balkanski chorizonti. Istorija, obštestva, ličnosti, t. I, Sofija, 2004 [Матанов Христо, Балкански хоризонти. История, общества, личности, t. I, София, 2004].

Mitova-Džonova Dimitrina, Confinium Succi i Mutatio Soneium prez antičnostta i rannovizantijskata epocha, „Anlali”, 1994, nr 1.2/3, s. 77-99 [Митова-Джонова Димитрина, Confinium Succi u Mutatio Sопеіит през античността и ранновизантийската епоха, „Анали”, 1994, $\mathrm{nr}$ 1.2/3, s. 77-99.].

Momčilov Dimčo V., Severoiztočna Trakija VII-X vek, „Epohi”, 1995, nr 3.2, s. 61-70 [Момчилов Димчо B., Североизточна Тракия VII-Х век, „Епохи”, 1995, nr 3.2, s. 61-70].

Momčilov Dimčo, Kultura i politika na Părvoto bălgarsko carstvo v Severoiztočna Trakija (po archeologičeski danni), Varna, 2007 [Момчилов Димчо, Култура и политика на Първото българско иарство в Североизточна Тракия (по археологически данни), Варна, 2007].

Momčilov Dimčo, Opit za demografska charakteristika na Severoiztočna Trakija VII-X vek, w: Prof. d.i.n. Stančo Vaklinov i srednovekovnata bălgarska kultura, red. Kazimir Popkonstantinov, Boris Borisov, Rosina Kostova, Veliko Tărnovo, 2005, s. 305-309 [Момчилов Димчо, Опит за демографска характеристика на Североизточна Тракия VII-X век, w: Проф. д.и.н. Станчо Ваклинов и средновековната българска култура, red. Казимир Попконстантинов, Борис Борисов, Росина Костова, Велико Търново, 2005, s. 305-309].

Momčilov Dimčo, Pătna i selištna sistema meždu Iztočna Stara Planina i „Erkesijata” IV-XIV v. (Vărbiški, Riški i Ajtoski prochod), Varna, 1999 [Момчилов Димчо, Пътна и селищна система между Източна Стара Планина и „Еркесията” IV-XIV в. (Върбишки, Ришки и Айтоски проход), Варна, 1999].

Momčilov Dimčo, Roljata na Anchialo i Markeli pri voennite konflikti meždu Bălgarija i Vizantija prez perioda na Părvoto bălgarsko carstvo, w: Velikotărnovskijat universitet „Sv. sv. Kiril i Metodij“ i bălgarskata archeologija, t. I, red. Boris Borisov, Veliko Tărnovo 2010, s. 437-448 [Момчилов Димчо, Ролята на Анхиало и Маркели при военните конфликти между България и Византия през периода на Първото българско ияарство, w: Великотърновският университет „Св. св. Кирил и Методий“ и българската археология, t. I, red. Борис Борисов, Велико Търново 2010, s. 437-448].

Mutafčiev Petăr, Balkanăt v našata istorija, w: idem, Kniga za bălgarite, red. Vasil Gjuzelev, Sofija, 1987, s. 65-89 [Мутафчиев Петър, Балканът в намата история, w: idem, Книга за българите, red. Васил Гюзелев, София, 1987, s. 65-89].

Mutafčiev Petăr, Istorija na bălgarskija narod /681-1323/, red. Vasil Gjuzelev, Sofija, 1986 [Мутафчиев Петър, История на българския народ /681-1323/, red. Васил Гюзелев, София, 1986]. 
Mutafčiev Petăr, Lekcii po istorija na Vizantija, t. II, red. Georgi Bakalov, Sofija, 1995 [Мутафчиев Петър, Лекиии по история на Византия, t. II, red. Георги Бакалов, София, 1995].

Mutafčiev Petăr, Starijat drum prez „,Trajanovi vrata”, „Spisanie na Bălgarskata Akademija na Naukite. Klon Istoriko-filologičen i Filosofsko-obšestven”, 1937, nr 55 (27), s. 19-148 [Мутафчиев Петър, Старият друм през „Траянови врата”, „Списание на Българската академия на науките. Клон Историко-филологичен и Философско-обществен”, 1937, nr 55 (27), s. 19-148].

Oikonomidès Nicolas, À propos de la première occupation byzantine de la Bulgarie (971 - ca 986), w: Eupsycheía. Mélanges H. Ahrweiler, t. II, Paris 1998, s. 581-589.

Oikonomidès Nicolas, Mesembria in the Ninth Century: Epigraphical Evidence, w: idem, Byzantium from the Ninth Century to the Fourth Crusade. Studies, Texts. Monuments, Hampshire 1992, s. 269-273.

Oikonomidès Nicolas, Tribute or Trade? The Byzantine-Bulgarian Treaty of 716, w: Studia Slavico-Byzantina et Mediaevalia Europensia. In memoriam Ivan Dujčev, t. I, red. Petăr Dinekov, Axinia Džurova, Georgi Bakalov, Krasimir Stančev, Georgi Minčev, Sofia 1988, s. 29-31.

Ostrogorski Georg, Dzieje Bizancjum, red. Halina Evert-Kappesowa, ${ }^{2}$ Warszawa 1968.

Ovčarov Dimităr Savov, Vizantijski i bălgarski kreposti V-X vek, Sofija, 1982 [Овчаров Димитьр Савов, Византийски и български крепости $V-X$ век, София, 1982].

Pertusi Agostino, La formation des thèmes byzantines, w: Berichte zum XI. Internationalen Bizantinisten-Kongreß, München 1958, s. 1-40.

Petrov Petăr, David, Mojsej, Aron i Samuil načelo na bălgarskata dăržava, w: Istorija na Bălgarija $v$ četirinadeset toma, t. II, Părva bălgarska dăržava, red. Dimităr Angelov, Sofija, 1981, s. 397-402 [Петров Петър, Давид, Мойсей, Арон и Самуил начело на българската държава, w: История на България в четиринадесет тома, t. II, Първа българска държава, red. Димитър Ангелов, София, 1981, s. 397-402].

Pletn'ov Valentin, Peev Preslav, Za srednovekovnija Varnenski pristan Roso/Rosito/Rosiko, w: Velikotărnovskijat Universitet "Sv. sv. Kiril i Metodij” i bălgarskata archeologija, red. Boris Borisov, t. I, Veliko Tărnovo 2010, s. 505-524 [Плетньов Валентин, Пеев Преслав, За средновековния варненски пристан Росо/Росито/Росико, w: Великотърновският Университет "Св. св. Кирил и Методий” и българската археология, red. Борис Борисов, t. I, Велико Търново 2010, s. 505524].

Pohl Walter, Die Awaren: ein Steppenvolk im Mitteleuropa, 567-822 n. Chr., Munich 1988.

Popović Vladimir, Kuvrat, Kuber i Asparuch, „Starinar“, 1986, nr 37, s. 103-126 [Поповић Владимир, Куврат, Кубер и Аспарух, „Старинар”, 1986, nr 37, s. 103-126].

Primov Borislav, Cankova-Petkova Genoveva, Bălgarija prez VIII в., w: Istorija na Bălgarija v četirinadeset toma, t. II, Părva bălgarska dăržava, red. Dimităr Angelov, Sofija, 1981, s. 110-130 [Примов Борислав, Цанкова-Петкова Геновева, България през VIII в., w: История на България в четиринадесет тома, t. II, Първа българска държава, red. Димитър Ангелов, София, 1981, s. 110-130].

Rašev Rašo, Bălgaro-vizantijskijat mir pri Varna ot 773 g., „Istorija”, 1999, nr 7.2/3, s. 81-85 [Рашев Рашо, Българо-византийският мир при Варна от 773 г., „История”, 1999, nr 7.2/3, s. 81-85].

Rašev Rašo, Poselištnijat život v Severna Trakija prez rannoto Srednovekovie, w: Severoiztočna Trakija i Vizantija prez IV-XIV vek, red. Dimităr Ovčarov, Sofija-Sliven, 1993, s. 101-117 [Рашев Рашо, Поселищният живот в Северна Тракия през ранното Средновековие, w: Североизточна Тракия и Византия през IV-XIV век, red. Димитър Овчаров, София-Сливен, 1993, s. 101-117].

Rašev Rašo, Starobălgarski ukreplenija na Dolnija Dunav /VII-XI v./, Varna, 1982 [Рашев Рашо, Старобългарски укрепления на Долния Дунав /VII-XI в./, Варна, 1982].

Rašev Rašo, Zemlenata ukrepitela sistema na Părvoto bălgarsko carstvo, w: Pliska - Preslav, t. II, Prabălgarskata kultura. Materiali na bălgaro-săvetskata srešta, Šumen 1976, red. Dimităr Angelov, Sofija, 1981, s. 99-103 [Рашев Рашо, Землената укрепителна система на Първото българско иарство, w: Плиска - Преслав, t. II, Прабългарската култура. Материали на българо-съветската среща, Шумен 1976, red. Димитьр Ангелов, София, 1981, s. 99-103]. 
Rochow Ilse, Kaiser Konstantin V. (741-775). Materialien zu seinem Leben und Nachleben. Mit einem prosopographischen Anhung von Claudia Ludwig, Ilse Rochow und Ralph-Johannes Lilie, Frankfurt am Main 1994.

Runciman Steven, A History of the First Bulgarian Empire, London 1930.

Sarantis Alexander, Justinian's Balkan Wars: campaigning, diplomacy and development in Illyricum, Thrace and the Northern World, A.D. 527-565, Cambridge 2016.

Sasselov Dimitar, Die frühmittelalterlichen Mauern am Meer von Nessebăr, w: Bulgaria Pontica Medii Aevi, t. III, red. Vasil Gjuzelev, Sofija, 1992, s. 227-232 [Sasselov Dimitar, Die frühmittelalterlichen Mauern am Meer von Nessebăr, w: Bulgaria Pontica Medii Aevi, t. III, red. В. Васил Гюзелев, София, 1992, s. 227-232].

Shepard Jonathan, Slavs and Bulgars, w: The New Cambridge Medieval History, t. II, c. 700-c. 900, red. Rosamond McKitterick, Cambridge 1995, s. 228-248.

Soustal Peter, Thrakien (Thrakē, Rodopē und Haimimontos), Tabula Imperii Byzantini, t. VI, Wien 1991.

Stanev Kamen, Trakija prez rannoto Srednovekovie, Veliko Tărnovo, 2012 [Станев Камен, Тракия през ранното Средновековие, Велико Търново, 2012].

Stoimenov Dimităr, Vremenna vizantijska voenna administracija v bălgarskite zemi (971-987/989), „Godišnik na Sofijskija Universitet. Naučen centăr za slavjano-vizantijski proučvanija «Ivan Dujčev»", 1988, nr 82 (2), s. 39-66 [Стоименов Димитър, Временна византийска военна администрация в българските земи (971-987/989), „Годишник на Софийския Университет. Научен център за славяно-византийски проучвания „Иван Дуйчев””, 1988, nr 82 (2), s. 39-66].

Swoboda Wincenty, Nicefor I, w: Stownik Starożytności Stowiańskich. Encyklopedyczny zarys kultury Stowian od czasów najdawniejszych do schytku wieku XII, t. III, $L-O$, red. Władysław Kowalenko, Gerard Labuda, Zdzisław Stieber, Wrocław 1967, s. 371-372.

Swoboda Wincenty, Powstanie państwa bułgarskiego na tle słowiańskich procesów państwowotwórczych na Batkanach, w: 1300-lecie państwa butgarskiego 681-1981. Materiaty z sesji naukowej, red. Tadeusz Zdancewicz, Poznań 1983, s. 67-76.

Swoboda Wincenty, Tema, w: Stownik Starożytności Stowiańskich. Encyklopedyczny zarys kultury Stowian od czasów najdawniejszych do schyłku wieku XII, t. VI, T-W, red. Gerard Labuda, Zdzisław Stieber, Wrocław 1977, s. 46-48.

Swoboda Wincenty, Tracja, w: Stownik Starożytności Stowiańskich. Encyklopedyczny zarys kultury Stowian od czasów najdawniejszych do schyłku wieku XII, t. VI, T-W, red. Gerard Labuda, Zdzisław Stieber, Wrocław 1977, s. 119-123.

Tăpkova-Zaimova Vasilka, Car Petăr. Vătrešno- $i$ vănšnopolitičeska dejnost, w: Istorija na Bălgarija v četirinadeset toma, t. II, Părva bălgarska dăržava, red. Dimităr Angelov, Sofija, 1981, s. 370374 [Тъпкова-Заимова Василка, Цар Петър. Вътрешно- и вънинополитическа дейност, w: История на България в четиринадесет тома, t. II, Първа българска държава, red. Димитър Ангелов, София, 1981, s. 370-374].

Tăpkova-Zaimova Vasilka, Frontières médiévales et réseau routier au sud du Danube, „Bulgaria Mediaevalis", 2010, nr 1, s. 1-15.

Tăpkova-Zaimova Vasilka, Kăm văprosa za voennite pătišta prez Părvoto bălgarsko carstvo, „Istoričeski pregled", 1958, nr 14.1, s. 58-73 [Тъпкова-Заимова Василка, Към въпроса за военните пътища през Първото българско царство, „Исторически преглед”, 1958, nr 14.1, s. 58-73].

Thompson Edward Arthur, The Huns, Oxford 1996.

Treadgold Warren, A History of the Byzantine State and Society, Stanford 1997.

Treadgold Warren, The Bulgars' Treaty with the Byzantines in 816, „Rivista di studi byzantini e slavi”, 1984, nr 4, s. 213-220.

Venedikov Ivan, Prabălgarite i christianstvoto, Stara Zagora, 1998 [Венедиков Иван, Прабългарите и християнството, Стара Загора, 1998].

Wasilewski Tadeusz, Bizancjum i Stowianie w IX wieku. Studia z dziejów stosunków politycznych i kulturalnych, Warszawa 1972.

Wasilewski Tadeusz, Historia Bułgarii, ${ }^{2}$ Wrocław 1988. 
Wasilewski Tadeusz, Kontrowersje wokót powstania i najstarszych dziejów państwa butgarskiego, w: Trzynaście wieków Butgarii. Materiaty polsko-bułgarskiej sesji naukowej, Warszawa 28-30 X 1981, red. Janusz Siatkowski, Wrocław 1983, s. 181-189.

Whitby Mark, The Emperor Maurice and his historian: Theophylact Simocatta on Persian and Balkan warfare, Oxford 1988.

Zlatarski Vasil Nikolov, Istorija na bălgarskata dăržava prez srednite vekove, t. II, Bălgarija pod vizantijsko vladičestvo (1018-1187), Sofija, 1934 [Златарски Васил Николов, История на българската държава през средните векове, t. II, България под византийско владичество (1018-1187), София, 1934]. 
